\title{
Agrarian social movements: The absurdly difficult but not impossible agenda of defeating right-wing populism and exploring a socialist future
}

\author{
Saturnino M. Borras Jr. ${ }^{1,2,3}$
}

${ }^{1}$ International Institute of Social Studies (ISS), The Hague, The Netherlands

${ }^{2}$ College at Humanities and Development Studies, China Agricultural University, Beijing, China

${ }^{3}$ Transnational Institute (TNI), Amsterdam, The Netherlands

\section{Correspondence}

Saturnino M. Borras Jr., International Institute of Social Studies (ISS), The Hague, The Netherlands.

Email: junborras5@gmail.com

\begin{abstract}
Parallels, resemblances, and interconnections between contemporary right-wing populism and the populism of agrarian movements are examined in this essay. The two are partly linked through their social base in the countryside. This paper explores an agenda for political conversation and research on possible contributions to the twin efforts of splitting the ranks of right-wing populists while expanding the united front of democratic challengers. The challenge is how to transform the identified interconnections into a left-wing political project that can erode right-wing populism. This requires a reclaiming of populism. In exploring this agenda, the paper revisits the ideas and practices of rightwing populism and agrarian populism and the awkward overlaps and fundamental differences between them. It concludes with a discussion on the challenge of forging a reformulated class-conscious left-wing populism as a countercurrent to right-wing populism, and as a possible political force against capitalism and towards a socialist future.
\end{abstract}

KEYWORDS

agrarian populism, La Via Campesina, left-wing populism, right-wing populism, socialism

\section{1 | INTRODUCTION}

Both in the past and at present, procapitalist, right-wing, or even fascist movements and political parties have often found support from rural communities. Yet there is nothing inherently conservative in rural politics: history has also 
shown how working people in the countryside-that is, peasants, landless labourers, and others-joined the proletariat and other social forces at the barricades and in the trenches during antifeudal or socialist revolutions and anticolonial national liberation struggles. Key questions that scholars have grappled with during the past century include how and why such radical transformations happened from one society to another, and with what implications, and which strata of the working people in the countryside were the most open to such revolutionary projects. Some of these scholars come from the same broad theoretical tradition but have competing interpretations, such as Wolf (1969) and Paige (1975); others represent opposing worldviews, such as Scott (1976) and Popkin (1979). But most of them were concerned with the "big picture" meanings and implications of the consciousness and exercise of political agency of working people in the countryside, as was Barrington Moore Jr. (1967). Their basic question was similar to that posed by Huizer (1975): how do peasants become revolutionary? Or indeed-the flip side-how do peasants become reactionary?

Although the era of peasant-based revolutions has passed, Huizer's question remains relevant and could be broadened and updated for the current global conjuncture, when there are parallels, resemblances, and interconnections between agrarian populism and the populism of broader political agitations that are regressive in nature and when the challenge is how to transform such interconnections into a political opportunity that can contribute to eroding right-wing populism. The question can be broadened by asking: how do "working people" in the countryside-peasants, landless labourers, indigenous communities, fishers, pastoralists, lower middle class, and the vast number of people in the informal sector including those who live and work in nearby small towns-become revolutionary? And it can be updated by asking: how could they join other social forces in the fight against neoliberal capitalism and contemporary right-wing populism and rally to support a reconceptualized notion of anti-capitalist left-wing populism that is broadly anchored on socialist principles? Socialism here is broadly defined, following Erik Olin Wright, as "a deeply democratic and egalitarian organization of power relations within an economy" (Wright, 2016, p. 102).

In my view, the current conjuncture calls, and could provide a fertile ground, for contemporary anti-capitalist agrarian social movements to propel a broad-based socialist agenda. At the same time, I would argue (a) that the future of contemporary agrarian social movements, including the broader food sovereignty movement, depends not only on how consistently anti-capitalist they are but even more importantly on their willingness and ability to build their movements and frame their agendas within a socialist framework and perspective (along with Wright's broad definition) or at least on their being not anti-socialist and thus their willingness and their ability to actively coconstruct a pluralist platform for a broad-based, common political project and (b) that it is essential that any antiright-wing populist political project centred on left-wing populism has a significant component, which comes from and relates to rural communities.

Historically, successful reforms or revolutions were direct outcomes of the dialectically linked weakening of a ruling elite and the strengthening of challengers. Political work in defeating contemporary right-wing populism thus cannot rely solely on either weakening right-wing populists or strengthening democratic challengers: both elements will be needed. It is in this context that the agrarian world could make important contributions to challenging resurging right-wing populism because it has the material basis and political potential to split the ranks of right-wing populists, at the same time that it can contribute to broadening a countercurrent of class-conscious left-wing populism.

This paper addresses the twin challenges of splitting the ranks of right-wing populists while expanding the united front of democratic challengers. It aims to explore an agenda for political conversation, primarily, and academic research, secondarily, on possible contributions to overall efforts at defeating contemporary right-wing populism. It builds on initial and often rough assumptions and tentative hunches and generates questions to which I do not have the answers. For instance, I do not know what foundational theoretical logic and practical political scaffolding are necessary and possible for building a class-conscious left-wing populism, beyond proposing a vision that is outside capitalism and which is framed here as a socialist alternative. Finally, I am writing this paper with practical political, and not academic, concerns as a principal starting point, coming from an activist world view. This is a continuation 
of the conversation with comrades inside the radical emancipatory movements in the Philippines during the late 1980s and the first half of the 1990s. ${ }^{1}$

In this paper, I use the term "populism" to mean "the deliberate political act of aggregating disparate and even competing and contradictory class and group interests and demands into a relatively homogenized voice, that is, 'we, the people', against an 'adversarial them' for tactical or strategic political purposes." As such, populism is inherently relational. It tends to be a means towards an end rather than an end itself, giving it a very generic character that is open-ended and flexible, facilitating easy adaptation by various ideological camps, even competing ones. Two types of populism are the main subjects of this paper. The first is right-wing populism, that is, a regressive, conservative, or reactionary type of populism that promotes or defends capitalism in the name of "the people"; in its current manifestation, it is also xenophobic, nationalist, racist, and/or misogynistic. The second is agrarian populism, that is, that political bundling of various rural-based or rural-oriented social groups and class interests and issues into a homogenized category, "the people of the land"; many variants of agrarian populism are anti-capitalist and try to advance a "peasant way" of alternative development.

I use the term "right-wing populism" for lack of a better term. The logic of the notion of "populism as a matter of degree" (see discussion in the next section) extends to the notion of right-wing populism; that is, some populist currents lean further towards the right than others, even when they are all fundamentally right wing, given that (a) they are champions of contemporary capitalism, although the latter may take a variety of forms; (b) they are generally antisocialist; (c) they have disdain for basic democratic institutions, especially human rights; (d) they share a tendency towards authoritarianism and militarism; and (e) they are xenophobic or racist, and many are misogynistic. Actually, existing populisms will not find a perfect fit in the term right-wing populism, but they have no better fit in other terms either, such as "authoritarian populism" (Akram-Lodhi, 2018), "populist authoritarianism" (Docena, 2018), neoliberal authoritarianism/authoritarian neoliberalism (Saad-Filho, 2018), or "populist nationalism" (Vanaik, 2017a, b; Win, 2018), as there will always be significant outliers. Most of these populist currents have a strong tendency towards authoritarianism, but again, it is a matter of degree, and a regime may dynamically oscillate towards and away from populism and authoritarianism (as in the case of Cambodia; see Schoenberger, Beban, \& Lamb, 2018). There will always be exceptions once we deploy a defining term, which is by nature a delimiting term. But resorting to using the unqualified term populism loses the distinct character of the political moment, which is partly marked by some kind and degree of "right-wing-ness" and "authoritarianism."

Moreover, the term "right-wing populism" dovetails with our subsequent discussion of a potential countercurrent, namely, a "reformulated left-wing populism." That discussion will clarify the fundamental differences between what is a right-wing or a left-wing populism, and demonstrate why such clarity is important. It will help to illustrate the absurdity of some casual commentaries that put the United States's Trump and Venezuela's Maduro in one basket, for instance. It will also show that the term left-wing populism suffers from a similar semantic problem: for example, Bolivia's Morales is a left-wing populist but arguably employs some capital-accumulation strategies with features that are more to be expected from a contemporary right-wing regime than a left-wing regime, such as neoliberal (neo) extractivism (McKay, 2017), just as the Workers' Party (PT) in Brazil under Lula and Dilma constructed a similar type of populism (Andrade, 2019).

Finally, the terms right-wing and left-wing populisms are used here rather like bookends, ie, as ideal types or as heuristic tools. In reality, only rarely will any populist current fit neatly into either ideal type. The bookends will, however, allow us to see a dynamic continuum rather than fixed categories in between, with populist currents and regimes

\footnotetext{
${ }^{1}$ An intense debate inside the Communist Party of the Philippines (CPP) and fraternal movements erupted in the late 1980s, leading to multiple breakaway groups during the first half of the 1990s. A significant part of that debate involved the National Peasant Secretariat of the CPP that started to experiment with newer forms and goals of peasant mass movement struggles relative to the Maoist orthodoxy of "people's protracted war." The leadership of the CPP dismissed such experiments as impetuous petty bourgeois neo-populism which were to be shunned and suppressed. Later, the broader party debate deteriorated into a "revolutionary-counterrevolutionary" framework in which any comradely discussion became impossible. I have been deeply involved in radical agrarian movements in the Philippines since the early 1980s and have thus been engaged in this debate not in the classrooms but in the trenches. For further background, see Franco and Borras (2009).
} 
consolidating features of one of the ideal types but regularly borrowing features from the other. We will see a shifting, fluid situation in which populists straddle various points between these bookends, constantly morphing away from ideal types. Perry Anderson's analysis of the brand of populism of Brazil's Bolsonaro and how it is similar to but at the same time significantly different from its contemporary counterparts in Europe or Trump is a good illustration (Anderson, 2019). This is an important feature of populism today, and one which renders the terms right-wing or leftwing populism imperfect and imprecise but analytically useful.

In its attempt at homogenizing disparate, often competing interests of various classes and groups, each of the contemporary right-wing populisms and progressive agrarian populisms is marked and defined by internal contradictions and, at times, antagonisms (based on class relations, ideological positions, political calculations, among others), even though the two ideologically opposed populist groups target broadly similar issues and adversaries. ${ }^{2}$ Scoones et al. (2018) offer a closer, if preliminary, look at the possible connection between authoritarian populism and the rural world, trying to frame new ways of asking questions in order to understand such a relationship. The current paper builds on this.

Despite big claims that the world is now urban, the fact remains that nearly half the world's population, that is more than three billion people, can be categorized as rural. Rural political tendencies have become swing factors in many settings and political moments, including electoral politics and democratization more generally. ${ }^{3}$ Where rural voters represent a sizeable proportion of voters, if not the majority, the influence of rural issues on populist discourses and agitation is significant. We saw this in the 2014 elections in India ${ }^{4}$ and in the current political situation in the Philippines, ${ }^{5}$ for instance. Even in societies where the rural population is no longer significant compared with that of cities and mega cities, votes from rural communities-which usually include small towns-can nevertheless be critical. This was true of the 2016 elections in the United States, ${ }^{6}$ the 2017 elections in Germany, ${ }^{7}$ and the 2018 elections in Russia ${ }^{8}$ and in Turkey. ${ }^{9}$ In some countries, there is no clear urban-rural divide in electoral voting behaviour but rather an upsurge of support in both urban and rural spaces for right-wing candidates, such as in the 2018

\footnotetext{
${ }^{2}$ Brass (1997) offers a critical examination of the relationship between the "new" right and what he clusters together and labels as new populism in the 1960 s through the 1990s, in which agrarian themes form (Brass argues), a common bond for the two. This speaks to the themes explored in the present paper, but with different categorizations of objects of analysis.

${ }^{3}$ For the latter, see Fox's edited volume on rural democratization with perspectives from Latin America and the Philippines (Fox, 1990).

${ }^{4}$ BJP and BJP Allies (National Democratic Alliance) won a combined total of 212 seats of the total 342 rural seats (out of the total 543 seats), as compared with Congress Party and Allies' (United Progressive Alliance) total of 40 rural seats. In terms of vote share, the National Democratic Alliance secured $36.9 \%$ of the total rural vote, compared with $23.7 \%$ for the United Progressive Alliance (NES, 2014, p. 130). Thanks to Amod Shah for alerting me to these data, and for helping me interpret them.

${ }^{5}$ According to the December 2018 Social Weather Station (SWS) survey, "74\% of Filipino adults said they were satisfied with Duterte's performance, whereas $15 \%$ were dissatisfied, for a net satisfaction rating of +60 , correctly rounded. This translates to a "very good" rating, said SWS. The remaining $11 \%$ were undecided. ... The survey also showed that his net satisfaction rating...in urban areas [was] +64 , [and] in rural areas: +57 [note: +57 for rural areas is just 3 points below the overall net satisfaction rating of +60$]. "$ (Bueza, 2018, n. p.).

6“Between 2008 and 2016, Republicans' share of the urban vote barely changed and Democrats' share fell by 4 points. In the suburbs, Republicans likewise did not change much, and Democrats lost 5 points. The shifts were larger in rural areas, where Republicans gained by 9 points, and Democrats lost 11 points. Of course, some places are more "rural" or "urban" than others-there is a continuum. Strikingly, as you move up that continuum, from the largest metro areas to the most isolated and sparsely populated rural areas, the vote steadily grows more Republican." (Kurtzleben, 2016, n.p.).

7“German right-wing party Alternative für Deutschland (AfD) finds more support in rural areas with aging populations: The AfD received $12.6 \%$ of all votes in the parliamentary election on September 24, 2017, making them the third most powerful party in the German parliament. ...Generally, the AfD performs better in rural areas with negative demographic trends-a phenomenon that occurs more frequently in eastern German districts than in western districts. This allows for the conclusion that perspective is lacking among those living in rural areas with negative demographic developments." (Franz, Fratzscher, \& Kritikos, 2018, p. 70). Thanks to Sofia Monsalve for bringing this to my attention.

${ }^{8}$ On the eve of the Presidential Election (February 18, 2018), the Russian Public Opinion Research Center VTsIOM conducted a survey: "If the presidential elections were held next Sunday and the list of candidates would look like this, then which of these candidates would you most likely vote for?" The results were as follows: $76.40 \%$ of rural residents would vote for Putin. The official results of the election (18 March 2018): 76.69\% of Russian people [not just rural] voted for Putin (VTsIOM, 2018). With thanks to Natalia Mamonova.

9"The AKP's vote share has been consistently higher in the countryside than in the cities. ...The approval of the constitutional amendment in the referendum on April 16, 2017, established a super presidential system without checks and balances. The amendment was passed with a slight majority (51.4\%), but the share of the yes vote in the rural areas was much higher, estimated to be between 56\% [...] and 62\% [...]." (Gurel, Kucuk \& Tas, forthcoming 2019 , n. p.).
} 
elections in Brazil. ${ }^{10}$ Moreover, recent transformations in the global political economy require a more nuanced understanding of intermediate geographic spaces, namely, small and medium towns that have internalized some features of both urban and rural social life. ${ }^{11}$

Furthermore, the issues that help condition the rise of populism in one geographic region may originate from or be linked to a distant place. For example, the rise of the populous and wealthier industrial belts in south-east China is linked to the massive rural-to-urban migration from other parts of China, the phenomenon of the left-behind population in the countryside, and the widening gap between rural and urban worlds that forced the national government to adopt a populist programme, the New Socialist Countryside. ${ }^{12}$ The rise of these Chinese industrial belts is linked in turn to the decay of many rural and urban communities in the United States that used to host factories, many of which shut down as corporate operations migrated to south-eastern China, among other destinations. Thus, the populist impulses in multiple settings-rural China, urban/industrial China, and deindustrialized, abandoned, and neglected rural and urban communities in the United States-are concretely connected. It is not surprising that, despite the differences between them, right-wing populists worldwide are increasingly supporting or encouraging each other. This has prompted Edelman to raise a question that needs serious reflection: "To what extent are the world's autocrats-Trump, Duterte, Erdoğan, Modi, Orbán, Putin, among others-simply a mutually reinforcing collection of erratic rulers? Or are they taking shape as a global authoritarian populist axis?" (Edelman, 2018, p. 1, emphasis added).

All these factors have resurrected the issue of agrarian populism in broad new ways, requiring us to revisit and critically examine it against varying contemporary populisms, especially right-wing populism. It is not only that contemporary right-wing populism has concrete links with the rural world but also that there are awkward parallels, resemblances, and interconnections between right-wing populism and agrarian movements, and these are not random accidents. The political economy upon which such populisms emerged over long periods of time (Akram-Lodhi \& Kay, 2010a, b) partly shapes the kind of broader politics that characterize the present conjuncture (Saad-Filho, 2018). The boundaries between right-wing populist currents and their social base in the countryside on the one hand, and the populism of agrarian movements on the other, are porous, blurred, and malleable.

It is in the context of this perspective on agrarian populism-partly in light of its possible interconnection with the rise of right-wing populism worldwide today-that we take up the (unexpected) suggestion of a leading sceptic of contemporary agrarian movements and food sovereignty, Henry Bernstein, to go "beyond the comfort zone of class purism" and not to dismiss today's agrarian populism. Revisiting the Russian revolution, Bernstein (2018, p. 1146) notes that the challenge for adherents of Marxist political economy, whose strength is in socioeconomic analysis, is to have a better grasp of agrarian politics:

The route from the former to the latter entails many additional determinations and complexities, as well as capacity to confront the contingent, the indeterminate and unanticipated, and to change positions that goes far beyond the comfort zone of class purism and other illusions. ... This points towards a paradox... namely that while the best of Marxism retains its analytical superiority in addressing the class dynamics of agrarian change, for a variety of reasons agrarian populism appears a more vital ideological and

\footnotetext{
${ }^{10}$ I thank Daniela Calmon for sharing with me comprehensive and fascinating data on the 2018 elections in Brazil and how these can be interpreted through the current paper's lens.

${ }^{11}$ In this context, the 2016 national elections in France merit a close and careful look. Nièvre, the poorest département in Burgundy, is a traditional heartland of the French left. For 40 years, it was the rural power base of the former socialist president François Mitterrand, who was the mayor of the small town of Chäteau-Chinon for 20 years. "This place has been leftwing since the French revolution," one local socialist politician boasted, adding that Nièvre was a focal point for the French resistance during the Second World War. And yet the Front National more than doubled its vote here in the previous regional elections, and it is here in Burgundy that Le Pen is hoping for some of her highest scores. ...Le Pen's rural target is not just farmers, who are shrinking in number in France and represent about $1 \%$ of the electorate. Her base comprises people living in modest towns and country villages far away from big cities, who have felt the sharp edge of France's decades of mass unemployment, who have seen factories close and local shops and services disappear; in places where the population is ageing, young people are leaving and those who stay have to drive long distances to see a doctor or sometimes even to post a letter. (Chrisafis, 2017, n. p.).

${ }^{12}$ See Ye, Wang, Wu, He, and Liu (2013).
} 
political force. ...In my view, the challenges facing any Marxist agrarian politics would be helped by critical engagement with the most progressive (anti-capitalist) of today's agrarian populism, and the diverse rural struggles it embraces, rather than dismissing a priori all agrarian populism as necessarily and equally 'wrong' and 'reactionary'.

In relation to Bernstein's proposition, it is worth stating again that by left-wing agrarian movements and the broad food sovereignty movements; I mean those social movements that are anti-capitalist in their ideological orientation, whether this manifests systematically or not, explicitly or otherwise. Many, but not all, of these movements have socialist ideologies, influences, and leanings or are, at least, not anti-socialist (especially when seen from Wright's broad definition of socialism, cited above). These are widely diverse social movements in terms of ideological and political provenance and are heterogeneous in their class origins and intersecting social identities. Their anti-capitalist stance is not uniformly, evenly, and consistently found across and within movements and does not emerge from a unified ideology. These are movements of small farmers from the industrial North, poor peasants from the Global South, landless labourers, migrant farmworkers, indigenous peoples, pastoralist organizations, fishers' movements, women's movements, environmental advocacy groups, climate justice associations, and various radical food activist groups-bound, to varying degrees, by some principles of food sovereignty-whose class formations are further complicated by their intersecting and messy social identities around gender, generation, race, ethnicity, religion and/or nationality. The La Via Campesina and the International Planning Committee for Food Sovereignty (with their regional and national affiliates) are the most politically significant and publicly known global hubs of these broadly left-wing agrarian social movements (Edelman \& Borras, 2016). These are the movements that are often lumped together, pejoratively, as populists and dismissed as such.

\section{WHAT IS POPULISM?}

What we are keen to examine, following Rancière (2016, p. 102), are the "diverse or even antagonistic figures of the people, figures constructed by privileging modes of assembling certain distinctive traits, certain capacities or incapacities: an ethnic people defined by the community of land or blood; ... an ignorant people that the oligarchs keep at a distance." Rancière elaborates that the "notion of populism itself constructs a people characterized by the formidable alloy of a capacity-the brute force of great number-and an incapacity-the ignorance attributed to that same great number" (ibid.). This connects with Laclau's unit of analysis, which is "not to be the group, as a referent, but the sociopolitical demand" of particular groups (Laclau, 2005, p. 224, original emphasis). It is in this political process that a section of the community/people gets projected as the people, and the people is reduced to mean that particular section (ibid., p. 214). With these basic concepts as reference points, we can construct a set of seven characteristics which apply to contemporary populism: (a) a matter of degree, (b) "politics of appearances," (c) a matter of variation, (d) oscillation between rhetoric and reality, (e) differentiated and layered in its composition, (f) politically volatile and capricious, and (g) relevant whether in or out of state power. These will be elaborated below.

First, populism is not an "either/or" question; rather, it is a matter of degree. It is better understood not as a thing but as a relationship, not in black and white, but in shades of grey, as we compare, for instance, the varying strands and degrees of populism, and tendencies towards militarism, authoritarianism, or democratization of Zimbabwe's Mugabe, Thailand's Thaksin, Philippines' Duterte, Cambodia's Hun Sen, Myanmar's Aung San Suu Kyi, India's Modi, United States's Trump, France's Le Pen, Turkey's Erdogan, Brazil's Bolsonaro, or Russia's Putin. As Laclau (2005, p. 45, original emphasis) puts it: "To ask oneself if a movement is or is not populist, is actually to start with a wrong question. The question that we should, instead, ask ourselves, is the following: to what extent is a movement populist?" The logic of this argument is derived from some of the key tasks of political actions to homogenize diverse interests (complementary, competing, or contradictory) of social groups and their political positions into a singular stand or voice, aimed at achieving greater salience partly by trying to deliberately blur or cloak the sharp 
contradictions and differences between social groups and classes, highlighting selective unified features that are usually deliberately distorted if not largely imagined. Often invoked is a homogeneous people.

Second, to a large extent, populism is about politics of appearances, having some parallels with Tsing's notion of "economy of appearances"; that is, "the self-conscious making of a spectacle [that] is a necessary aid to gathering investment funds" (Tsing, 2000, p. 118). She elaborates, "In speculative enterprises, profit must be imagined before it can be extracted; the possibility of economic performance must be conjured like a spirit to draw an audience of potential investors. The more spectacular the conjuring, the more possible an investment frenzy" (ibid.). We can call the right-wing populist political version of Tsing's "economy of appearances" the politics of appearances: the self-conscious making of a spectacle that is a necessary mechanism in gathering political support. The possibility of political performance must be conjured like a spirit to draw an audience of potential voters, supporters, and investors; the more spectacular the conjuring, the more possible a frenzy of political support. Of course, all "politics" engages in "politics of appearances"; the difference with contemporary right-wing populism is the deliberate attempt at making a spectacle. All right-wing populist agitations engage in spectacles (where spectacular activities and leaders feed into each other; see also Saad-Filho, 2018 in the context of Bolsonaro in Brazil), although their core group, supporters, and sympathizers are investing political support as a form of speculation for rewards or benefits in the shape of social reforms or for rent-seeking opportunities.

Third, there are varied types of populism in relation to democracy and authoritarianism. There are right-wing and left-wing authoritarian populisms, and in between them lies a diversity of possible combinations. Authoritarianism, seen as a dynamic political process, is inherently uneven and replete with contradictions, and a regime is seldom completely democratic or totally authoritarian. Populist currents malign the institutional establishment with pejorative labels, such as "establishment insiders," for very tactical reasons and moments. They eschew or try to subvert conventional institutions, at least selectively and tactically. Furthermore, competing variants of populism do coexist at the same time and in the same political-administrative territory and do clash head-on: Trump versus Sanders in the United States in 2016 and Le Pen versus Melenchon in France in 2017 are examples. It is within this wide-ranging terrain that one has to examine populists' attitude towards social structures and institutions or towards the character of the state (e.g., class basis and ideology) and following Scoones et al. (2018), debates on key concepts like authoritarian populism (Hall, 1985).

Fourth, populism oscillates between rhetoric and reality, that is, "populism in word" and "populism in deed." Many of the neoextractivist left-wing regimes in the Latin American "pink tide" governments veered towards populism in deed, at least partially. One of the defining features of these regimes has been the adaptation of extractivist neoliberal capitalism with accompanying distributive social reforms, such as cash transfer schemes and food distribution programmes carried out by governments under the leadership of Lula and Dilma in Brazil, Morales in Bolivia, and Correa in Ecuador-at times under creative populist banners such as buen vivir, or indeed, "food sovereignty" (see Arsel, Hogenboom, \& Pellegrini, 2016; Chappell, 2018; Gudynas, 2011; Veltmeyer \& Petras, 2014; Vergara-Camus $\&$ Kay, 2017). Many of these reforms are now under threat from a resurgent right in the region. Meanwhile, several right-wing populist groups got into power on the promise of sweeping social reforms, but there remains a huge gap between what was promised and what was delivered. Whether this will continue to be the case is something to watch closely.

Fifth, a populist current (right-wing populists or progressive agrarian movements) is inherently internally differentiated and layered in terms of groups and political tendencies. The layers include leaders, a core group, and a social base of supporters and sympathizers. These sets of actors have varying agendas, roles, and degrees of commitment to the framing of the populist agenda and agitation, which are not necessarily unified, with each one trying to use the other. A core group is usually a mixture of diverse subgroups: ideologues committed to particular worldviews, oligarchs, racists, and sublayers of brokers, speculators, scammers, swindlers, and often circles of organized crime. The willingness of ordinary people to let populist leaders claim them, act in their name, speak on their behalf, and bundle them together as the people (with the whole group often rebundled in an even narrower manner, to be known simply by the name of the populist leader) may not reflect their belief in and commitment to the populist rhetoric or trust 
in the populist leader. It may only indicate that their distrust in the old establishment or traditional elitist system is so deep that they prefer to take a gamble on something different and unconventional. Moreover, a core group, or subgroups within a core group, does not emerge from nowhere. A broad right-wing populist agitation (broad, in the sense that it includes diverse currents of conservative and right-wing groups) mobilizes and emboldens moribund or marginalized fringe groups engaged in hate politics, such as White supremacists and other racist groups and religious extremists whether of Buddhist, Christian, Hindu (Vanaik, 2017a, b), or Islamic (Hadiz, 2016) variants.

Sixth, each layer of actors within a populist group (leader, core group, sympathizers, or supporters) is politically volatile and capricious in an ever-fluid situation, where the leadership, core group, and mass base may behave differently over time, often in self-contradictory ways. They can change their discourse at any time, as they are situational and tactical but at the same time strategic in their political calculation. Duterte in the Philippines is an example: engaging in left-wing rhetoric one day and right wing the next day (Curato, 2017). This capriciousness is largely determined by the constant need to conjure a spectacle based on what the ringleaders think the people want or do not want.

Seventh, a populist group is relevant whether in or out of state power. The right-wing agitations that we are interested in may or may not be in power, but their significance stands, regardless. Their location vis-à-vis state power has an influence on most of the characteristics discussed here, such as how they frame their discourse or forge alliances. Right-wing populists that gain state power do not necessarily change the character of the state (class basis, ideology); rather, they tend to focus on changing the regime of political rule and determining who is in and out in government among the factions of the ruling classes and social groups. At the same time, right-wing populists that are outside state power should not be dismissed or taken for granted because they can significantly influence the character and trajectory of state power. Even where other political parties promise never to include them in a coalition, the emergence of parties like Geert Wilders' Party for Freedom in the Netherlands has forced ruling coalitions to adopt some of the right-wing populists' rhetoric and policies. Some groups long considered to be fringe groupings and politically irrelevant and unpopular could, in the event of a sudden change of political conjuncture, reinsert themselves into a broader and more significant right-wing populist current, such as the White supremacists and alt-right in the United States, in Austria, Germany, and Sweden, the region of Andalucía in Spain (with the rise of the Vox party in the 2018 elections), ${ }^{13}$ or even in Indonesia, as seen in the rising influence of Islamist groups. Right-wing populism, viewed from an "inside/outside the state" perspective, is better seen as a continuum and from a long historical sweep. Indeed, understanding Trump's right-wing populism and the progressive populism of the La Via Campesina and its U.S. affiliates requires us to understand the long history and moments and instances in different historical conditions of American populist agitations (see Chrisman, 2016; Gaventa, 1982; Hobsbawm, 1987, p. 36; Taggart, 2000, p. 34).

The issue of populists being in or out of state power is partly related to the discussion on the episodic character of populism. Mouffe (2005, p. 70) concludes that "It is no doubt encouraging to see that the appeal of [right-wing political parties] diminishes once they become part of the government, and that they seem able to thrive only when in opposition." Taggart (2000, p. 106) similarly argues, "The episodic nature of populism as a political phenomenon owes much to its highly ambivalent relationship to institutions. This makes it necessarily short-lived." I agree that populism tends to be episodic, but I am not convinced by the explanations of Mouffe and Taggart. One defining character of the political moment is precisely that many right-wing populists are in power and utilizing the very institutions they once selectively attacked. In my view, the reason for the episodic character of populism is not due to populists'

\footnotetext{
${ }^{13}$ The Vox party in Spain has become the first far-right group to triumph at the ballot box because of the country's return to democracy after the death of Francisco Franco in 1975. Vox...exceeded all predictions to take 12 seats in the Andalucían regional election on Sunday. Although the ruling Spanish socialist party (PSOE) won the elections, taking 33 of the 109 seats in the regional parliament, its support collapsed in the heartland it has ruled since 1982. Even with the support of the Podemos-led Adelante Andalucía coalition-which won 17 seats-the PSOE would still be short of the 55 seats needed for a majority in the regional parliament. The conservative People's party took 26 seats, whereas the centre-right Ciudadanos party won 21 . Were the two rightwing parties to join forces with Vox, they would jointly command a majority, with 59 seats. (Jones, 2018, n. p.). In January 2019, the three right-wing parties brokered an agreement that guarantees that the People's party candidate will become the next regional president. This will be the first time since the end of Francoism that Andalucía has a right-wing government.
} 
ambivalence towards formal liberal institutions, but rather, it is a result of the cyclical nature of the crises of capitalism and by extension, the crises of political rule (see also the analysis by Saad-Filho, 2018 on Brazil).

\section{I IMPORTANT DEBATES ON AGRARIAN POPULISM}

There is nothing inherently progressive in agrarian populist movements-despite the often celebratory claims by such social movements and their supporters in contemporary agrarian politics. Historical cases include instances when agrarian movements took a conservative or reactionary political stance. One objective of this essay resonates with Paxton's reason for studying the 1920s and 1930s French countryside in order to understand fascism in France. Paxton (1997, p. 6) laments, "[I]t was in the countryside that both Mussolini and Hitler won their first mass following, and it was angry farmers who provided their first mass constituency. Yet, so far, every student of fascism in France has ignored the countryside." He concludes, "Given the salience of angry farmers in the success of fascism elsewhere and the importance of the peasantry in the French society, that is a crippling omission" (ibid.). Today, nearly all of the right-wing populists, both those in power and those not (yet) in power, have very significant electoral and political support from the rural population. How are we to understand this situation, and what is to be done?

Populist agitation is always antagonistic to an "other." The "us" cannot be constructed without conjuring up a "them." But to the extent that the us is defined or constructed, this is always framed as "the anti-status quo," "the anti-establishment," "the subaltern," "the underdog," "the wronged," "the violated," "the looked-down," "the pushed aside," "the left-behind," or "the challenger." ${ }^{14}$

In critical agrarian studies, populism has a broad meaning similar to that discussed so far. The provenance of contemporary agrarian populism is the left-wing Russian narodniks during the second half of the 19th century who aimed to overthrow tsarist rule and to rescue the surviving Russian peasant communes (obshchina) and their organizational structure (mir), which they believed could contain the seed for a possible socialist future. Narodnism (narod broadly means people) was a "restorative struggle" with a tendency to romanticize communities where capitalist relations had not yet fully taken hold. Thus, the peasantry was seen as a route to socialism without having to pass through the capitalist phase of development.

It was estimated that about 2,000 to 3,000 urban students went to the Russian countryside in 1874, with a certain degree of spontaneity, without any written programme or organization. These young intellectuals did not know much about peasant life or the practicality of political work. "Moving from village to village, they distributed revolutionary pamphlets and talked indiscriminately to the peasants who crossed their path about the need to radically redistribute land and engage in revolution" (Taggart, 2000, p. 50). The narodniks would soon be frustrated by what they discovered about peasants' politics: the peasantry did not have the appetite for revolution. The urban intellectuals imagined and expected peasants "to be oppressed, idealistic and ripe for revolution. In practice they found the peasants to be acquisitive, conservative and profoundly suspicious of the students" (ibid., p. 52). Many of these peasants would tip off the authorities about the presence of the narodniks. By 1877, most of the students, about 1,611, had been arrested. In Taggart's words (ibid., p. 52), "The summer of 1874 showed what a group of activists could do. More than that, it showed what the peasantry would not do." The narodniks shifted strategy from educating the peasantry to engaging in armed struggle, in the form of assassination attempts at the tsarist authorities, especially the tsar, some successful, mostly not. Two organizational groupings came about, "Land and Freedom" (Zemlya i Volya) and the "People's Will" (Narodnaya Volya); the latter successfully assassinated Tsar Alexander II in 1881 (see also Bernstein, 2018).

The intellectuals in the People's Will read Capital and got into direct contact with Karl Marx. Vera Zasulich wrote to Marx: "[W]e often hear it said that the rural commune is an archaic form condemned to perish by history, scientific socialism and, in short, everything above debate. Those who preach such a view call themselves your disciples par excellence: 'MarksistsMarxists." She continued, "Their strongest argument is often: "Marx said so". You would be

${ }^{14}$ See further elaboration in Panizza (2005). 
doing us a very great favour if you were to set forth your ideas on the possible fate of our rural commune, and on the theory that it is historically necessary for every country in the world to pass through all the phases of capitalist production" (Zasulich, 1983, p. 98-99 [original February 16, 1881]). To which Marx responded, after several lengthy draft versions of his reply, "The analysis in Capital...provides no reasons either for or against the vitality of the Russian commune. But the special study I have made of it, including a search for original source material, has convinced me that the commune is the fulcrum for social regeneration in Russia" (Marx, 1983, p. 124 [original March 8, 1881]). The exchange between Zasulich and Marx has been the subject of much controversy and debate in the literature of Marxist agrarian studies about populism (see Bernstein, 2018; Shanin, 1983a).

Although the original Russian populism was short-lived, its legacy and influence would continue on, partly because of its key element, namely, its principal commitment to socialism-albeit trying to take a route via the peasantry. As Hobsbawm (1987, p. 199, cited in Bernstein, 2018, p. 1131) puts it, narodnism "is not significant for what it achieved, which was hardly anything, nor for the numbers it mobilised, which hardly exceeded a few thousand ... [but that it] ... formed, as it were, the chemical laboratory in which all the major revolutionary ideas of the nineteenth century were tested, combined and developed into those of the twentieth century." These ideas were inextricably linked to parallel and subsequent debates in Marxism, from Engels' formulation of the peasant question and Kautsky's formulation of the "agrarian question" (Engels, 1894; Kautsky, 1988 [orig. 1899]), to Russian revolutionary ideas and practices from Leninism and the Chayanovian socioeconomic logic of the peasant economy (Lenin, 2004 [orig. 1905]; Chayanov, 1966, [orig 1925]), ${ }^{15}$ and even to contemporary Marxism (see Akram-Lodhi \& Kay, 2010a,b; Levien, Watts, \& Yan, 2018)-all of which are relevant in the current, early 21st century conjuncture. Narodnism, decimated after 1881, was reincarnated "in the form of a 'Social Revolutionary' party in the early 1900s," and it would "become the major rural party of the left" (Hobsbawm, 1987, p. 295). For Shanin (1983b, p. 271),

The crux of the originality and illumination of the Russian revolutionary populist lies ... in the posing of a number of fundamental questions concerning capitalist society, its 'peripheries' and the socialist project. The attempts to disqualify those questions as belonging to the past only, i.e. representing the Russian social backwardness in the 1880s or the petty bourgeoise nature of its peasantry, have proved wrong by historical experience. The decline of peasant Russia did not make those questions disappear; quite on the contrary, most of them became increasingly global and pertinent also in super-industrial environments. Such questions left unanswered come back to haunt socialists time and time again, and will proceed to do so until faced, theoretically and politically. They can be avoided only at socialism's peril.

It is important to clarify a central point: how did the politically loaded term populism originate, evolve, and come to have such a negative meaning in the Marxist academic and political tradition? In the history of some communist parties, "(neo)populism" was viewed from a "revolutionary-counterrevolutionary" framework that could-and did -lead to recurring bitter factional purges, a position impacted by a small but, at some point, influential section of sectarian Marxists. We turn to Shanin once again for his interpretation of the history of this term that is central in the current paper. He explains it in the context of Marxism and the narodniks, demonstrating that the history of this term was intertwined with right-wing populism:

The label 'populist', like that of 'marxist', is badly lacking in precision; the heterogeneity of both camps was considerable. In Russian speech a populist (narodnik) could have meant anything from a revolutionary terrorist to a philanthropic squire. What makes it worse is the fact that there are today no political heirs to claim and defend the heritage of Russian populism - political losers have few loyal kinsmen, while the victors monopolise press, cash and imagination. Lenin's major work ... from which generations

\footnotetext{
${ }^{15}$ Chayanov's theories of the peasant economy would become a key influence in subsequent agrarian discourse and among towering agrarian scholars such as Shanin (1972), Scott (1976) and van der Ploeg (2013). The extent to which the original narodnism and Chayanov have informed contemporary agrarian populism is something that, in my view, is generally assumed or theoretically extrapolated rather than demonstrated. This is relevant, especially because most of the important agrarian movements do not make explicit the theoretical provenance of their political frameworks, and the few that do refer explicitly to their theoretical inspirations actually invoke Marx, and sometimes even Lenin-but never Herzen, Chernyshekvskii or Chayanov.
} 
of socialists learned their Russian terminology, used 'populism' as a label for a couple of writers who stood at that time on the extreme right wing of the populists. ... This made Lenin's anti-populist argument of 1898 easier, while increasing the obscurity of the populist creed to his readers of today. (Shanin, 1983a, p. 8)

Agrarian populism is plural and diverse. Terence J. Byres, in his 1979 classic critique of the populism of Michael Lipton (1977), identified three types of agrarian populism: classical populism, neopopulism, and liberal populism (Byres, 1979). He would later, in 2004, advance the notion of neoclassical neopopulism to categorize the body of work of Griffin, Khan, and Ickowitz (2002), as well as Lipton. ${ }^{16}$ Neopopulism is essentially identified with Chayanov (1966 [original 1925]). Byres' basis for categorization includes the position taken on social differentiation among the peasantry, the role of rich peasants, industrialization, revolution, private property, and socialism. It is a useful heuristic tool that can help improve our understanding of the so-called agrarian populist movements today, within and across right-wing and left-wing agrarian movements. This is particularly helpful when problematic narratives tend to assume that the neoclassical economics version of populism is progressive, whereas Marxist advocacy for socialism is outdated and dogmatic.

Following Byres' categories and looking at the examples of the La Via Campesina and the International Planning Committee for Food Sovereignty, one can conclude that the majority of the affiliated movements have the following characteristics: (a) anti-capitalist; (b) not antirevolution; (c) not antiindustrialization (although industry and progress have to be redefined); (d) believe in the power of small farmer production-but only under certain conditions of democratic property regimes and technological advancement; (e) do not consider people in the countryside to be an undifferentiated mass; and (f) do not support the polarized view of the "oppressed rural mass versus urban oppressors." Are there tendencies within these movements to gravitate around each of Byres' ideal-type populisms? Definitely. Some members of the La Via Campesina from Central and Eastern Europe do not want to hear anything about a socialism especially of the type that existed in their region in the past (although they may be open to the kind of socialism defined by Wright). In addition, the key La Via Campesina movements in India are champions of Byres' neopopulist pole. Tendencies to pick up some elements of classical populism, especially those combining an anti-capitalist and socialist discourse, with agrarian societies as spearhead, are palpable in some discourses of influential individuals and movements within some sections of the La Via Campesina. Yet, on the opposite pole, one will see a commitment to Marxism, or even disciplined adherence to classic Leninist principles, from other member movements of La Via Campesina. What appears at the first sight as a unified position within the La Via Campesina as a global movement is in fact better seen as a series of temporary outcomes of conjunctural political struggles internal to the movements that are in turn underpinned by various ideological currents. Understanding these ideological currents is key, and Byres' typology of agrarian populism is a useful reference point.

Following this discussion around Byres' categories of agrarian populism, it becomes relevant to see Bernstein's (2018) emphasis on not dismissing a priori agrarian populists as, partly and importantly, a methodological question that calls for concrete analysis of concrete conditions. Heeding this call and taking a closer look at contemporary agrarian movements, we will see highly differentiated national and transnational agrarian movements (TAMs) based on class, ideology, and politics (Borras \& Franco, 2009; Edelman \& Borras, 2016). However, there is a persistent

\footnotetext{
${ }^{16}$ In his 1979 critique of Lipton, Byres argued that Lipton embraces classical populism in as much as he has "an almost mystical faith in the mass of the people (who happen to be rural 'countryfolk') - not some of the people, but all of them who are capable...of uniting against their urban oppressors and establishing egalitarian Utopia" (Byres, 1979, p. 238). He further characterized Lipton as a classical populist because of his belief that "the small farmer is more efficient...than the large," as well as "a distaste for industry and a conviction that industrialization...is undesirable; an anti-capitalist stance; a determination to confront and reject Marxism, allied to a curious fascination with Marxist ideas" (ibid.). Byres then argued that Lipton is a neopopulist because of his "defense...of rich peasants...in his claim that he actually accepts the need for industrialization, but in the distant future, and not if an efficient agriculture is possible; and in his aversion to revolution" (ibid.) Byres tagged Chayanov (1966 [original 1925]) as the father of neopopulism. Finally, Byres argued that Lipton is a liberal populist because of his "aversion to revolution" and "accompanying professed faith in reformist solutions and in the power of reason and argument to secure social justice (even from dictators)" (ibid.). Twenty-five years later, Byres (2004) criticized the work of Griffin, Khan, and Ickowitz (2002) on land reform, implicating Lipton, and put forward an argument that Griffin et al. and Lipton are in fact "neoclassical neopopulist," with their fundamentals anchored in neoclassical economics. For the latest relevant discussions, see Bernstein (2018); Bernstein, Friedmann, van der Ploeg, Shanin, and White (2018); van der Ploeg (2018, 2013); White (2018).
} 
tendency in the debates to see and label them as a unified and homogeneous movement. They are not. The various social groups that comprise this catch-all category of "agrarian (neo)populism"-and the movements that compete to (re)present these, separately and collectively-are linked through class relations, and their internal politics are, at times, marked by antagonism. The breadth and diversity increase as these (sub)national movements link horizontally across classes and unite vertically as they forge transnational coalitions. It is therefore unfortunate that such movements are often lumped together, understood and labelled, a priori and pejoratively, as amorphous agrarian populist movements, and dismissed on that basis. Such tendencies can inadvertently undermine the potency of the Marxist framework in advancing urgent and necessary critiques of contemporary agrarian movements on many fundamental issues, such as uneven and inconsistent anti-capitalist stance and campaigns; reluctance to take an explicitly socialist platform; inconsistent position and actions in explicitly building class-conscious broader alliances among working people, especially among landless labourers in the countryside; and other class-oriented issues for which a Marxist framework is best positioned.

Contrary to the caricaturized depiction of agrarian neopopulism, many of the key movements within the La Via Campesina represent entirely different stories. I will illustrate this point by looking at three of the founding members of the La Via Campesina, namely, Brazil's MST (Movimento dos Trabalhadores Sem Terra), which is a broadly Marxist agrarian movement (Wolford, 2010), the Philippine Peasant Movement (Kilusang Magbubukid ng Pilipinas), which is within the close orbit of a Marxist-Leninist-Maoist left movement (Borras, 2007; Franco, 2011; Putzel, 1995), and Andalucía's Sindicato Obrero del Campo, which comes from a broad left-wing tradition with significant anarcho-syndicalist influences. All three movements are anti-capitalist, with broad socialist perspectives, and all have played key leadership roles in the La Via Campesina at various stages of the history of this transnational movement. These three movements do not have a perfect fit in the description of classical agrarian populism, or in any of the subsequent formulations of neopopulism; none of the three movements are nostalgic-romantic, conservative, reactionary, or utopian; none of the three are class-blind in their political work; none of the three are antiindustrialization; and they bear little resemblance to any of the prominent Indian rich peasant movements in terms of class base, ideology, and politics. These movements take agrarian landed classes as the principal class adversary, with demand for land as central-even when they take agribusiness based outside the countryside as equally important targets. This is fundamentally different from rich peasant agitations, such as those in India, that deliberately avoid landed classes as targets and land redistribution and labour issues as central demands and instead target "urban elites" and/or foreign corporations as the principal adversaries. My hunch is that it is most likely that the overwhelming majority of the movements affiliated with the La Via Campesina are closer, in varying degrees and extents, to MST, Kilusang Magbubukid ng Pilipinas, or Sindicato Obrero del Campo in terms of social base, ideology, and politics than to the caricature of an agrarian populist, whether classical or neo. Interpretation, presentation, or claims about these social movements by observers- allies, advocates, admirers, and/or sympathizers of agrarian movements, whether academic researchers or NGOs-may not always be a precise reflection of what actually exists and cannot replace the need for more careful empirical investigation of such questions.

There are also two international farmer federations which are worthy of note here, namely, the International Federation of Agricultural Producers (established in 1946 and self-liquidated in 2010; Desmarais, 2007) and, arguably, its reincarnation in the form of the World Farmers Organization (Edelman \& Borras, 2016). These organizations are movements of rich commercial farmers or are politically led or influenced by the latter; they are largely based in industrialized countries with a few members in developing countries that represent medium-scale and rich agricultural producers and farmers, such as the Zambia National Farmers' Union. Their sets of demands are fundamentally different from the La Via Campesina's. Generally, they are defenders of capitalism and opposed to socialism. They endorse the World Trade Organization, with reforms. Most of them can easily fit in Byres' categories of "liberal populism" and/or neoclassical neopopulism.

It will be interesting and important to examine whether and how, and to map the extent to which, their mass bases are linked to contemporary right-wing populism and compare whether progressive agrarian populists acted differently as compared with their conservative counterparts in interacting with or confronting right-wing populism. 
It is, for example, important to investigate empirically-rather than assume theoretically-how members of the European Coordination Via Campesina and the European affiliate of the World Farmers Organization (and International Federation of Agricultural Producers previously), namely, Committee of Professional Agricultural Organizations/General Confederation of Agricultural Cooperatives, are voting in the contemporary electoral contests across Europe. It is legitimate to ask because we know that the rise of right-wing populist groups in Europe today, from France to Sweden and from Austria to Germany, has been electorally supported by rural voters. There is a material basis here for possible contradictions, including the fact that many of the farmers associated with these organizations are likely to be engaged in hiring (sometimes illegal) migrant farmworkers from Eastern Europe or North Africa, an issue that is at the heart of the right-wing upsurge. In a similar vein, it would be relevant to examine more closely the politics of their American counterparts, such as the Farm Bureau, especially in relation to their attitude towards Trump's position on immigration, on the one hand, and the issue of widespread reliance on (sometimes illegal) farmworkers from Latin America, on the other hand. Indeed, it is important to interrogate the two key gatekeepers of the La Via Campesina in South Asia, namely, the Karnataka State Farmers Association and Bhartiya Kisan Union, not just in terms of the Modi regime but especially on the broader issue of rising Hindu populist nationalism (Vanaik, 2017a,b) and the demands they are putting forward to the current national government more broadly. These are empirical questions.

The justification for the lengthy discussion above is to demonstrate that agrarian populism is, in reality, far more differentiated than its homogenized and caricaturized depiction by some sections of the Marxist intellectual community (academics or party cadres). Deliberately lumping groups together or failing to discern this differentiated nature can lead to a flawed deployment even of objectively rigorous theoretical ideas and can result in unfortunate or even disastrous political miscalculations in terms of practical politics; or worse, as is often the case, it can lead to such movements-all movements-being dismissed altogether. Conservative rich peasant movements exist, but these are not included in the broader category of "progressive agrarian populism/ populists" that I use in this paper, the minimum defining character of the latter being that they are radically anticapitalist.

Contemporary progressive agrarian movements are relatively vibrant, as even sceptics like Bernstein (2018) admit. Based on our definition of populism discussed above, I would argue that their political actions are populist centrally because they are attempts at rebundling socioeconomically differentiated class and group interests and issues into a more homogenized voice-"people of the land"-in relation to a constructed "other." The rise of TAMs during the past couple of decades, particularly the La Via Campesina, and the subsequent platform for action, that is food sovereignty, are perhaps the most significant political processes in the social justice movements' global front because neoliberalism took a hold in the early 1980s and subsequently debilitated conventional workers' trade unions and movements (Desmarais, 2007; Edelman et al., 2014; Edelman \& Borras, 2016; Martinez-Torres \& Rosset, 2010; McMichael, 2008; Shattuck, Schiavoni, \& VanGelder, 2015; Wittman, Desmarais, \& Weibe, 2010). The La Via Campesina is, in practice, a populist movement, based on our definition of the term (which is not necessarily pejorative). As we have emphasized earlier, this brand of agrarian populism is not necessarily class blind, as is often insinuated in polemics.

More generally, the assumption that populism and class blindness necessarily and always go together should be interrogated empirically. In my view, it is precisely the class consciousness within some of these TAMs and food sovereignty movements that has led them to aggregate disparate interests and demands among differentiated social classes and groups in political projects that are deliberately framed as multi-class initiatives. This does not mean they were able to resolve the inherent contradictions, or even antagonism, in some of the social relations that underpin potential movement participants, for example, farmers and (migrant) farmworkers or rich farmer movement versus poor peasant movement members. It only means that these class dynamics are actually flagged and are being addressed even if unevenly and inconsistently within and between many of these movements across societies, across political spaces, and over time. This is a necessarily tension-filled and conflict-ridden process, an arena of struggle within and among movements. This issue remains one of the most underexplored themes in the study of 
contemporary agrarian movements: one possible reason for this is because it is an extremely sensitive issue and thus quite difficult to research.

Moreover, and relatedly, many serious scholars studying agrarian movements and politics in and related to the countryside who do not identify their scholarship solely, fully, and strictly with orthodox Marxism are not necessarily class blind or uninformed by relevant Marxist concepts about questions of agency and politics-as a quick, random glance at some of the influential work of numerous important scholars from across disciplines and generations would remind us. ${ }^{17}$ A simplistic, polarized division of progressive researchers in critical agrarian studies between strict orthodox Marxism on the one hand and an ideal-type Chayanovian neopopulism on the other hand does not fully capture the diversity of intellectual and political currents that actually exist and is, politically, not very productive.

Meanwhile, it is equally important to emphasize that even class-based politics is, like agrarian populism, diverse and plural. Dogmatic interpretations of Marx and Lenin, or of Mao, is one strand but is not the only possible route to the interpretation of class-based politics, as the contrasting approaches to understanding agrarian class agency and agrarian class politics by Eric Wolf (1969) and Jeffrey Paige (1975), for instance, remind us. ${ }^{18}$

\section{I POPULISM, CLASS POLITICS, AND CRISIS}

In the era of contemporary right-wing populism, class and class politics have become even more relevant. E.P. Thompson (2013, p. 9, [orig. 1968]) explains that "the class experience is largely determined by the productive relations into which men [sic] are born-or enter involuntarily. Class-consciousness is the way in which these experiences are handled in cultural terms: embodied in traditions, value-systems, ideas and institutional forms." He elaborates further, "If the experience appears as determined, class-consciousness does not. We can see a logic in the responses of similar occupational groups undergoing similar experiences, but we cannot predicate any law." "Consciousness of class," he concludes, "arises in the same way in different times and places, but never in just the same way" (ibid.).

Right-wing and left-wing populists are two ideologically opposed groups targeting broadly similar issues and antagonists. Thus, even though each takes an adversarial and antagonistic stance towards the other, their discourse, actions, and shared elements of their anti-establishment narratives can be objectively mutually reinforcing. In the 2016 U.S. elections, Bernie Sanders' attack against "the establishment" for having caused the closure of American factories was cast firmly within an anti-capitalism/anti-neoliberalism frame, whereas Donald Trump, also speaking out against factory closures, did not blame capitalism/neoliberalism but unpatriotic American corporations. Sanders and Trump both gained popularity in the U.S. rust belt communities. It is thus not surprising that the social base of an insurgent right-wing populist group can sometimes also be the mass base of a challenger left-wing/progressive initiative or at least the boundaries between them can be porous, blurred or malleable. The partially overlapping mass (class) bases usually comprise those who are not part of the ideological core of the right- and left-wing populist groups and can constitute the swing vote that can be lured from left-wing issues to right-wing populism and vice versa. Again, the American rust belt politics during the 2016 U.S. elections is a good example, with traditionally Democrat states voting for Trump when Sanders failed to become the Democratic Party presidential candidate. ${ }^{19}$ Sanders and Trump are ideological opposites for some of their core groups-"alt-right" for Trump, socialists for Sanders-but they have common supporters and sympathizers, and the basis of the latter, at least in the beginning, is not their ideological stances, but the immediate, concrete issues addressed, such as factory closures amid corporate migration outside

\footnotetext{
${ }^{17}$ For example, Baud and Rutten (2004); Baviskar (1999); Clapp and Isakson (2018); Edelman (1999); Fairbairn (2014); Hall (2011); Holt-Giménez (2017); Isakson (2014); Li (2007, 2014); Martinez-Alier (2014); McMichael (2008); Moore (1967); Newell and Wheeler (2006); Patel (2009); Peluso (1992); Peluso and Lund (2011); Ribot and Peluso (2003); Scoones (2015); Scott (1976, 1985); Shanin (1972); Tsikata and Yaro (2014); Weis (2007); Wolford (2010).

${ }^{18}$ And as some more recent studies point out, such as Bernstein (2018), Bernstein et al. (2018); Cousins, Dubb, Hornby, and Mtero (2018); Lerche and Shah (2018); Levien et al. (2018); White (2018).

${ }^{19}$ For elaboration and insiders' accounts, see Sanders (2016) and Bond and Exley (2016).
} 
the country. We see this dynamic play out across various themes and regions of the United States, such as coal mining and the Appalachian communities. ${ }^{20}$

Right-wing populist groups and anti-capitalist agrarian movements are both insurgent anti-establishment challengers, although they tend to operate on different scales (with the former often in the spotlight of big politics). Transnational agrarian movements like the La Via Campesina and food sovereignty movements are populist movements in the sense discussed in this essay. They juxtapose the people or the "community" as the us, and the big corporations (agrochemical corporations, food empires, banks, and so on) and landed classes and oligarchs as the "them." Similarly, the progressive left-wing slogan, "the $1 \%$ versus the $99 \%$," is a populist but definitely class-conscious formulation in relative terms, compared with Trump's populism that deliberately lumps together those in the $1 \%$ and the $99 \%$. But still, the formulation of "99\%" conceals important class conflict and tension and is problematic in many ways. The way food and agrarian movements construct powerful punchy slogans reflects such consciousness in the constant invocation of the us and the other: "industrial agriculture heats up the planet, small-scale agriculture cools down the earth," "not about us without us," "people before profit," "no to agriculture without farmers," "small-scale farmers feed the world," or "World Trade Organization kills." Their ability to condense complex conditions of their disparate base in short, graphic slogans that become key reference points and mobilizing narratives is a brilliant populist strategy of constructing the us and its other.

Many contemporary right-wing populist groups have evolved in a similar manner by aggregating disparate social classes and groups in the rural world, forging a homogenizing discourse (i.e., deliberately class-blinding narratives) and projecting a future in ways that converge somewhat with agrarian movements and food sovereignty movements, even when the basis, reason, and implications are fundamentally different. Le Pen's projection of "the forgotten French countryside" ${ }^{21}$ resonates with Confederacion Paysanne's long-standing framing of these issues-but the two perspectives are ideological opposites as to why this happens and what is to be done.

The feeling of extreme frustration is common to both the right-wing populist mass bases and agrarian movements. In many contemporary settings, this mounting frustration derives from problems around cheap food provisioning, social security and health care, jobs, neglect of public services, social decay including the menace of drug addiction, absence of redistributive reforms like land reform, persistent violence and criminality, rural-urban migration flows, and massive indebtedness ${ }^{22}$ that, separately or together, generate much angst and anger among people in (the cities and) the countryside. These issues are magnified during socioeconomic and political crises. It is the crisis situation that provides the fertile ground for the populist seed to grow: the fact or threat of socioeconomic losses among ordinary people-not only the working class, or "subproletariat," but also the middle class, as argued by Perry Anderson in the context of the rise of Bolsonaro in Brazil (Anderson, 2019) and Bello in the context of Chile, Thailand, and the Philippines historically (2018)-together with the state's inability or unwillingness to act according to what people perceive to be its moral obligation to respond in times of crisis. To make matters worse, in many instances, it is the state that takes the lead in assaulting the remaining potential capability of poor people for social reproduction, namely, dispossessing poor people of their access to land, often without offering alternative livelihood or employment (Levien, 2011; Li, 2010, 2011; Wolford, Borras, Hall, Scoones, \& White, 2013).

Crisis revives the collective memory of past cycles of broken promises or broken systems. It is the simultaneous convergence of multiple crises-including crisis in political rule (see, e.g., Anderson's analysis of the rise of Bolsonaro in Brazil [Anderson, 2019])-that has triggered the current right-wing populist upsurge. Historically, the rise of rightwing populism has been a response to, or accompanied by, crisis. The French "Greenshirts" peasant movement of the 1920s and 1930s emerged in response to a triple crisis: economically ("an ever-deepening decline of farm prices that lasted so long and plunged so low that even the most diligent efforts could barely keep a family alive"), culturally

${ }^{20}$ This is well captured in the video: https://www.youtube.com/watch?v=eqceHviNBC4 (viewed 19 October 2018).

${ }^{21}$ As depicted for instance in the video: https://www.youtube.com/watch?v=N-ooZ96nA8g (viewed 19 October 2018).

${ }^{22}$ Gerber (2014) offers a powerful analysis of the role of debt in capitalism, with reference to the rural world, which is extremely relevant in deeper analyses of the politics of right-wing populism and the countryside but cannot be elaborated further here for reasons of space. 
("the low esteem for peasants" life, values, and needs'), and politically (a "crisis of representation"; Paxton, 1997, p. 11). These past cycles of broken promises of rural reforms and reform of the global food system have led to the accumulation of frustration and anger among rural and urban social groups and the rise of relatively vibrant left-wing transnational agrarian, environmental, climate justice, and food sovereignty movements-all with strong populist impulses and tendencies. They are increasingly linking their movements together. ${ }^{23}$

Yet the same manifestations of capitalism in crisis have also spurred the current right-wing populist agitations, although the latter frame such crises differently, as for example, the climate change denial of right-wing U.S. populists, Trump's electoral promise to revive the dying coal industry and the Brazilian Bolsonaro's similar spin on these issues (Saad-Filho, 2018). Whether and how the Trump administration will fundamentally differ from past administrations in terms of its treatment of American agriculture and the countryside remains to be seen, although current indications suggest that it will continue with similar policies. As Chrisman (2016, p. 1) explains "[a]s of 2012, just four percent of farms produced two-thirds of agricultural value-that's a lot of wealth concentrated in just a few hands. Today, a small number of farmers are 'efficiently' producing more grain than ever, while metropolitan and suburban populations have ballooned." She continues, "But what of those who remain? 46 million Americans still live in the countryside, with many hollowed out towns, few job prospects, and the near impossibility of making a living off the land for all but the biggest farm operators" (see also Edelman, 2018; Ulrich-Schad \& Duncan, 2018).

How the converging multiple crises are experienced and what impacts they have on the dynamic reconfiguration of material class interests and social identity formation across social classes and groups in society provide part of the basis for an objective alliance between right-wing populism and agrarian populism to emerge. In other words, although their actions are independent from each other and they may even take an adversarial stance against each other, they actually reinforce one another. The danger will come if and when this objective alliance evolves into a subjective alliance, that is, the conscious construction of an organized coalition of forces and actions. If this were to happen, with disgruntled rural populations voting en masse for right-wing candidates, the forces of reaction could gain much ground and political momentum. One challenge, therefore, is how to prevent any transformation of the existing objective alliance into a subjective alliance between right-wing populism and agrarian populism, or even how to undermine the objective alliance between them. Holt-Giménez and Shattuck (2011) offer powerful analytical and political reference points about some of these key issues in relation to food movements. ${ }^{24}$

Social media is a crucial instrument in the dynamic and fluid construction of populist identities (see Soriano, 2015) for both types of populisms discussed here. Social media enabled, facilitated, and expanded right-wing populists' tactical rejection of conventional and institutionalized channels of contact with ordinary people. This was most effective in penetrating the countryside in the fastest way possible and without filters from traditional elite brokers such as churches or small town caciques and other elites. Smart phones, Facebook, and Twitter have, under certain conditions and in various ways, democratized access to information, whether fake news or otherwise and provided mass access to photo, audio, and video technology and resources with ease and minimal cost. The traditional role of elite allies of geographically and socially marginalized rural population-rural school teachers, church leaders, educated young intellectuals, caciques, and others (a key subject of research in classic agrarian studies)-has been radically transformed and increasingly replaced by more diverse in situ and distant information brokers and populist agitators. For example, a blogger and social media agitator who is part of the core group of a right-wing populist leader can have millions of followers on Twitter or Facebook, including those who live in the countryside. Clearly, this can be a double-edged sword: the same technologies enabled the volunteers for Sanders to directly, quickly, and frequently connect with millions of people who would become supporters of the electoral insurgency; but the right-wing upsurge led by Trump was also largely enabled by the same technologies.

${ }^{23}$ See Borras, Moreda, Alonso-Fradejas, and Brent (2018); Brent, Schiavoni, and Alonso-Fradejas (2015); Claeys and Delgado Pugley (2017); Edelman and Borras (2016); Tramel (2016, 2018); Mills (2018).

${ }^{24}$ See also Roman-Alcalá (2018) for a related argument. 
While recognizing the dangers inherent in the expansion-in numbers and political influence-of core groups linked to right-wing populism, there are also dangers in fighting them. The way that some groups oppose right-wing populism by addressing populist leaders, core groups, and supporters can have an impact on whether the right-wing group is undermined or consolidated and expanded. Some popular ways of confronting right-wing populist groups are deeply problematic: for instance, considering a populist group to be ideologically homogeneous; perceiving a rightwing group to be homogeneous in terms of social class, race, and ethnicity; and assuming that there are no inherent contradictions within right-wing populist groups between leaders, core group, supporters, and sympathizers.

Moreover, dismissive, insulting, or condescending remarks addressed to leaders, core group, or supporters and sympathizers can, under certain conditions, have a counter-productive effect, consolidating the group's perception of the antagonism between them (as the underdog) and the others (the elite). Fake news is generated and routinized in this process. For instance, insulting Red Shirt movement participants as stupid, ignorant peasants might help to strengthen and expand the populist core group among Thailand's northeast rural communities. Mocking Duterte supporters for their imperfect and unpolished Tagalog (the minority language of the national capital and the traditional elite) might only consolidate Duterte's base and maintain his popularity. Addressing mainstream parties and media, Santiago Abascal, leader of the far-right Vox party that made major electoral gains in the Andalucían regional elections in 2018, put it succinctly: "You haven't understood anything. ... Every time you insult us, you are insulting the millions of Spanish people who listen to us and identify with our message" (Jones, 2018, n.p.). When any of these things happen, there is a danger that the core group grows as disgruntled supporters and sympathizers join them, thus strengthening the previously tenuous relationship between populist leaders and their mass sympathizers. This inadvertently supports the deliberate efforts by right-wing populists to downplay or dismiss class differentiation among their mass base, cementing the feeling that the latter is a homogeneous mass that has been uniformly wronged. This volatile scenario is even more pronounced in the era of social media where the back-and-forth exchanges are often public and where passions flare up so quickly.

\section{5 | THE FUNDAMENTAL DIFFERENCES BETWEEN RIGHT-WING POPULISM AND PROGRESSIVE AGRARIAN POPULISM TODAY}

It is important not to forget that, historically, rural social classes and groups have a checkered record in terms of supporting right wing, even fascist political projects. The contemporary rural support for Trump in the United States (Ulrich-Schad \& Duncan, 2018), Putin in Russia (Mamonova, 2016, 2018, forthcoming 2019), Le Pen in France, Erdogan in Turkey (Adaman, Arsel \& Akbulut, forthcoming 2019; Gurel et al., forthcoming 2019), Modi in India, the Red Shirt movement in Thailand supporting Thaksin (Nishizaki, 2014), and the Greenshirts of 1920s and 1930s French led by Henry Dorgeres (Paxton, 1997) all remind us of past and present rural support to right-wing political ideas and initiatives. Bello (2018) offers a critical reflection on the relationship between the rise of fascism, the peasantry, and the middle class in Chile, Indonesia, Italy, the Philippines, and Thailand, seen from the contemporary context. While not forgetting and dismissing the problematic ties between right-wing populism and agrarian populism, it is also important to identify and clarify the fundamental differences and the bases for these. We can see this in a number of ways, two of which are as follows.

On the one hand, contemporary right-wing populists and progressive agrarian populists essentially differ in their take on the nature and causes of the current crises and how to address them, as mentioned earlier. Although both populisms have elements of nostalgia, the right-wing current is straightforwardly reactionary: defending or promoting capitalism, or at least particular types of capitalism, such as Trump's "Make America Great Again" agitation or Bolsonaro's nostalgia of past Brazilian military rule and hope for a neoliberal capitalist future projected via his Trumpian slogan, "Make Brazil Great." Many, though not all, progressive agrarian and food sovereignty movements may have strong tendencies towards restorative and nostalgic narratives ("everything was fine before the agribusiness came to our villages" sort of formulation), but in contrast to right-wing populism, these are usually set within 
broader and longer perspectives of emancipatory struggles towards alternatives to, or alternatives within, capitalism (Holt-Giménez \& Shattuck, 2011; Wright, 2016).

On the other hand, the strategies and forms of collective action of right-wing populists and progressive agrarian populists tend to be generally antagonistic to each other. Although it is not inherent in right-wing populism to be militarist or fascist (it can be at home with liberal democracy, as arguably demonstrated by the populist Corazon Aquino government [1986-1992] in the Philippines ${ }^{25}$ ), recent and current right-wing populist variants are susceptible to or inclined towards militarist and fascist tendencies. In contrast, contemporary progressive agrarian movements, especially those allied in the La Via Campesina, are deeply and fundamentally opposed to militarist and fascist methods of political rule. Right-wing populists have disdain for human rights principles, laws, institutions, and activists, whereas progressive agrarian movements have made human rights central in framing their political struggles (Monsalve, 2013). Food sovereignty itself is founded on the broad framework of human rights (Claeys, 2012), just as its core component of agroecology has been framed by a section of the human rights community (De Schutter, 2014).

As discussed above, the rise of right-wing populism is partly due to the multiple crises caused by capitalism in a situation of unprecedented levels of wealth and affluence amid unprecedented degrees of inequality and precarity, in an ecologically fragile world. Right-wing populist agitations are anchored in a rhetoric in which salvation, ironically, is thought to depend on capitalism-the very cause of the crisis, which the populist agitation purports to address. Unfortunately, the contradiction in this is not always obvious. This is where agrarian movements and food sovereignty become a potent social force that, together with other progressive social forces, can make a modest but significant contribution to countering the rise of right-wing populism. They are able to do this for a number of material reasons.

First, shared narratives about those who were/are in state power causing much of people's misery-whether because they are too soft or too hard on corporate giants, among others-easily resonate across sympathizers of both right-wing populist groups and agrarian movements. Second, as already mentioned, right-wing populist groups and agrarian movements may share a far larger common mass base in the countryside (and beyond) than perhaps we imagine. The general feeling of neglect, lack of wealth and power redistribution, joblessness, and social decay in the countryside can easily become key issues for both political groups. Third, agrarian movements and food sovereignty movements are often marked by their multi-class character, and they have, on many occasions, been able to cross class lines to forge broader alliances. For example, rural constituencies for food sovereignty have forged alliances with urban sectors: workers, urban poor communities, middle class urban consumers, and so on. There is an interesting difference or disconnect between the conditions of urban and rural classes and groups and the populisms that emerge from their narratives or movements. In general, urban working class and precarious middle class demand jobs, which gives the narrative of right-wing populism considerable currency in these communities, whereas progressive agrarian populists' principal demand is land (and to some extent, jobs). ${ }^{26}$ If they can be cast in terms of a broader anti-capitalist agitation, these two sets of contemporary urban and rural demands (which make Kay's, 2009 revisiting of the classic debate on "urban bias" between Byres, 1979 and Lipton, 1977, both useful and timely) could dismantle the propoor façade of right-wing populism or that of conservative agrarian populism (especially agrarian neopopulism led by rich peasants) and put them on the defensive.

Fourth, despite their encompassing agenda, agrarian movements rarely aspire to replace an established faction of the elite in state rule, in the way that most "big politics" right-wing populists do. This is a double-edge sword, depending on specific context, because the agendas of agrarian movements can be, and have been, vulnerable to co-optation by the establishment they detest or by other populist groups, left wing, or right wing. There are ample examples of

\footnotetext{
${ }^{25}$ Where this type occurred, the ruling classes did not hesitate to mobilize the coercive power of the state to suppress democratic dissent, as exemplified for instance in the Mendiola Massacre of January 22, 1987 when the military and police guarding the Presidential Palace in Manila open fired on a 20,000 strong peasant march demanding land reform, killing 13 and wounding dozens more (Borras, 2007). See also: https://www.youtube.com/watch?v= wsXocipaJKA (viewed 20 January 2019).

${ }^{26}$ This also differentiates them from the conservative version of agrarian populism that is usually anchored in rich farmers' demands, namely, productivist and remunerative issues.
} 
this in Latin America's "pink tide" countries where food sovereignty has been enshrined in the constitution or in national governmental policies but interpreted in ways that contradict social movements' understanding, such as the incorporation of food sovereignty into the broader buen vivir platforms, funded, ironically, through neoextractivism (see Andrade, 2019; Clark, 2017; Giunta, 2014; Henderson, 2018; McKay, Nehring, \& Walsh-Dilley, 2014; Vergara-Camus \& Kay, 2017). The Zero Budget Natural Farming movement founded by Subhash Palekar in India has gained much momentum, praise, and support from Prime Minister Modi, but its awkward or even troubling overlap with the right-wing Hindu nationalist current poses difficult challenges and dilemmas even for its supporters from among the organized progressive agrarian populists. In a critical reflection, Khadse, Rosset, Morales and Ferguson (2018, p. 214) admit that "there is sometimes an uncomfortable closeness of some elements of Palekar's discourse to that of Hindutva's cultural chauvinism," in addition to their observation that the majority of the Zero Budget Natural Farming members are from the "dominant caste/middle class."

Fifth, there is one institutional connection that links current agrarian and food sovereignty movements to rightwing agitation, even if they generally despise each other, namely, NGO funding. However, the link operates in a competing, contradictory way. ${ }^{27}$ The rise of the global NGO complex and its multibillion dollar annual funding portfolio has had a strategic impact on social justice movements because the latter have been among the recipients of such funding. A significant chunk of this funding is government money from donor countries that is distributed through the international aid infrastructure, following the logic of the neoliberalization of the development aid sector. Many NGOs have bought into the framework that promises to deliver concrete reforms that are measurable and based on "inclusive multistakeholder" events. This has resulted, among other things, in advocacy for specifically identifiable and countable individual or household "beneficiaries" of specific projects. Often, these projects conveniently and deliberately omit or completely dismiss class-oriented demands and actions as something unfeasible (it might be nearer the truth to admit that they are unfundable). For instance, society-wide land reform was dropped in favour of targeted participatory community-based formal land titling; struggles for just systems of production and trade were replaced with initiatives for farmers to become inserted into the global value chain. This has transformed many social movements and NGOs by making them more politically moderate, stripping them of their original defining features: a radical social justice agenda for systems change, irreverence, and subversiveness. Despite the problematic character of the NGO fund distribution infrastructure, it has been a critical pillar supporting the rise of social justice movements, especially agrarian and environmental movements, and enabling them to maintain a significant presence. However, the rise of right-wing populism in many Organisation for Economic Co-operation and Development countries, and the accompanying demands to end such funding, have rendered this NGO complex politically vulnerable. Some funding facilities have already partially collapsed amid right-wing pressure to get rid of them, or to redirect the funds to promoting the interests of national corporations (e.g., funds to promote "trade not aid," and directly related to national corporations). It is plausible that the weakened global donor complex has correspondingly weakened agrarian movements and their allies worldwide. One possible unintended-but positive-outcome of such a shift could be greater autonomy for agrarian movements. The challenge is how to extricate NGOs from their current entanglement with government funds, reclaim their subversive roots, and strengthen their deep commitment to autonomy, social justice, and help in building mass movements.

The final fundamental material basis that I want to note here for the opposite worldviews of right-wing populism and progressive agrarian movements is their competing notions of property or claims to fruits of labour. This is powerfully illustrated in the contrasting ideas about property around land, as argued by Wolford (2005) in the context of Brazil: MST's notion of property is based on the principle of "land for those who work it," in contrast to the landed elite's principle of land for those who have a stronger legal claim in terms of productivity and the ability to buy land in a free market. Such contrasting views were played out in the late 1990s in the context of the World Bank's marketassisted land reform and are now being resurrected in the Bolsonaro era. Following Wolford (2005), it is likely that

${ }^{27}$ The discussion on this issue draws on Edelman and Borras (2016), especially the chapter on the global NGO complex and its implications for agrarian movements. 
social relations around property and labour will remain among the most important defining elements that differentiate or create cleavages between progressive agrarian populism and right-wing populism.

\section{I WHAT IS TO BE DONE? ASK BIG AND ACT INSURGENT, WITH A SOCIALIST PERSPECTIVE}

The "consensus at the centre" has dominated mainstream responses to addressing contentious issues confronting the people. This consensus, Mouffe (2016, p. 64, emphasis added) argues, "removes from politics one of its constitutive elements-its partisan nature." The consensus seeks reforms within the framework of "what is doable," leading to its inability-or unwillingness to even try-to go beyond the limits imposed by the status quo. Perhaps what is needed is a strategy of "what is possible." The difference between the two is that the former works within the limits and vpossibilities of what is doable within a given balance of social forces, whereas the latter takes an insurgent approach to disrupt a given balance of social forces in order to pursue transformative deep social reforms. It pertains to what is possible in terms of disrupting the pre-existing balance of social forces and power in order to effect radical reforms that are otherwise unthinkable, and daring to tackle political agendas that are absurdly difficult but not impossible. ${ }^{28}$ As Eric Olin Wright (2016, p. 102; original emphasis) reminds us,

Pessimism is intellectually easy, perhaps even intellectually lazy. It often reflects a simple extrapolation of past experience into the future. Our theories of the future, however, are far too weak to really make confident claims that we know what can't happen. ...The appropriate orientation towards strategies of social transformation, therefore, is to do things now which put us in the best position to do more later by working to create those institutions and structures that increase, rather than decrease, the prospects of taking advantage of whatever historical opportunities emerge.

The problems confronting the rural world are huge, persistent, and entrenched. Reviewing how capitalism has, over time, condemned humanity and ecology to their current dire situation, Patel and Moore (2017, p. 41) suggest that there is an urgent "need to dream for more radical change than contemporary politics offer." ${ }^{29}$ The working class and the middle class worldwide were angry and were demanding radical reforms. Right-wing populists answered their call-with programmes that were big and insurgent-with relative success (in right-wing terms), and in many places in the world, at least for now.

Is it politically unfeasible to ask big and act in an insurgent way in a radically progressive context? Becky Bond and Zack Exley (2016) of the Bernie Sanders "political revolution" platform and campaign do not think so: In fact, they think that it is the only way to go forward. They have shown, from the trenches, that it is absurdly difficult but not impossible. Bond and Exley's book's title, Rules for Revolutionaries, is not randomly catchy. It is in direct conversation with Saul Alinsky's classic book, Rules for Radicals (Alinsky, 1971). Bond and Exley recognized that the contribution made by Alinsky was his central focus on the value of community organizing, anchored on immediate, concrete issues that could deliver palpable gains to community members, all done using organizing and mobilizing methods that are subversive and irreverent. Alinsky's approach found wide-ranging adherents worldwide, including, not surprisingly, among those who would become actors in middle-of-the-road politics.

Ultimately, however, Alinsky's approach only aspires to alleviate the condition of poor and socially marginalized local communities. For the Sanders team, the nature and extent of problems go far beyond a local community and are so enormous that real solutions require agents of social change to think big, to demand system change, and to use and pursue appropriate creative and insurgent methods of work and scale of mobilization. This was subsequently

\footnotetext{
${ }^{28}$ The concept of "difficult but not impossibly difficult; meaning, agendas that are absurdly difficult but not impossible" is inspired by and draws from the debate between the dwarf Balin and the grey wizard, Gandalf, on the latter's proposed strategy of stealth to tackle the dragon Smaug in the Lonely Mountain by recruiting a hobbit, namely, Bilbo, in J.R.R. Tolkien's Unfinished Tales, (Tolkien, 1980, pp. 430-431). See Ferguson (2015) for a framing of the enormity of such a challenge (of the politics of distribution) and why we should not back away from it.

${ }^{29}$ For a related discussion, but with more elaboration in the context of agrarian struggles, see Borras and Franco (2018).
} 
framed in an open call for a political revolution by the $99 \%$, that is, the people-the working class and the middle class -with a socialist perspective, as the Sanders campaign put it, generating political, financial, and logistical support from millions of ordinary people, especially from among millennials. It was a populist electoral insurgency, of a kind that was unheard of in the annals of American history. Sanders did not win the Democratic Party primary, but the campaign and the movement left us with a political treasure trove to mine for our own political projects wherever and whatever these might be. The principles of ask big, act insurgent, and dare to boldly advance a democratic socialist perspective in a context of a political revolution may actually gain traction in far more places than many might have conservatively assumed. "Audacity is crucial...and if the democratic and progressive forces do not adopt a bold stance, we can be sure that the extreme right will do so," as Inigo Errejón (2016, p. 67), political secretary of Podemos in Spain, reminds us (see also Franquesa, forthcoming 2019. ${ }^{30}$

Before going into some propositions on what is to be done, I will look briefly at three existing strategies used in struggles against right-wing populism, which are popular but may actually be problematic. The first is engaging in and mobilizing around restorative narratives and campaigns, insinuating that the period prior to right-wing populism was good for the people. This is quite a popular tactic worldwide, especially among those who were in power prior to the current populist upsurge, such as liberal democrats and social democrats. There is thus a compelling need to take a two-pronged approach to social struggles, striking simultaneously against the old regime and against the current right-wing upsurge.

The second is the contribution of small-scale and "too polite and neat" campaigns and mobilizations to subverting right-wing populism: however, well intentioned, these may prove to be insignificant. One aspect of the "consensus at the centre" approach that is partly responsible for the current right-wing populist swing is the dogmatic imposition of "multistakeholderism"-the codification of multistakeholder approaches (McKeon, 2018) to resolving class and identity conflicts, which completely fail to acknowledge the presence of power imbalances along class and other social hierarchies. Grand mismatches abound: for huge problems around the despotism of local rulers and chieftains, the answer is community-based conflict resolution mechanisms; for problems caused by extreme greed and bullying, practised with impunity by transnational corporations, the answer is multistakeholder platforms around voluntary self-regulation; for the problem of land grabbing, the answer is transparent and consultative administrative processes in land deals. There are serious class and power imbalances in these spaces where dominant actors actively ignore or deliberately misunderstand politicized notions of "accountability" (Fox, 2007; Gaventa, 2006; Ribot, 1999), or deliberately avoid radical interpretation and the use of governance instruments such as Free, Prior, Informed Consent (Franco, 2014).

The third strategy is sectoral struggle (e.g., trade union or peasant or urban-centred political work) against rightwing populism. This is a necessary but insufficient banner for social justice framing and for a spearhead social movement that can unite the working class and others sectors and social groups that are struggling, or have the potential to struggle, against right-wing populism. In many societies today, the scale of operations and exposure of agrarian movements and food sovereignty movements is limited and small relative to that of right-wing populism. In fact, the ideas and organizations of agrarian and food sovereignty movements in these societies shrink dramatically when viewed from the perspective of big politics, which right-wing populist groups steer. Today, the rural cannot be automatically equated with agricultural; many rural-based small and medium sized towns have emerged worldwide, and these are becoming hotspots for right-wing mass base building.

In the era of converging global crises and right-wing populist agitations, the need for radical, deep social reforms has only grown more urgent. Five goals of deep social reforms and ways to pursue them are relevant in the current

\footnotetext{
${ }^{30}$ The outcome of the late 2018 election in Andalucia offers an important insight in understanding the rise of right-wing populists and the resistance to it. According to Jaume Franquesa, "In terms of geographical and class spread, Vox's results are also interesting. Vox (and the whole right, in general) has done better in cities than in the countryside, and within those cities, it has done particularly well in wealthy neighborhoods. But Vox has obtained very high results in several municipalities with highly marketized, migrant labor-based agriculture, the most eye-catching example being El Ejido-a place where there was a terrible antimigrant pogrom at the turn of the century-which was the only Andalusian municipality where Vox won the election (with about $30 \%$ of the vote)." Personal email communication with Jaume Franquesa, December 4, 2018. See also Franquesa (forthcoming 2019) for a broader discussion in the context of the Spanish experience more generally.
} 
conditions of the rural world, namely, redistribution, recognition, restitution, regeneration and, resistance-or in short, revolution. ${ }^{31}$ These are deep reforms that are directed at the heart of social structures and institutions that reflect and maintain class formation and class rule, and could, or should, ratchet up towards structural transformation that could undermine capitalism and pave the way for a socialist alternative. Such a set of radical reforms does not recoil from class politics; in fact, class politics is at the heart of the 5 Rs.

The proposed agenda for political conversation, namely, deep social reforms, is fundamentally different from the dominant "third way" or social-democratic reforms because the latter actually legitimize and strengthen capitalism through incremental reforms that are ameliorative at best ${ }^{32}$ because they shy away from addressing existing class antagonisms and thus class politics. If taken seriously, the 5Rs proposed here constitute a political revolution and not just a reform programme. These $5 \mathrm{Rs}$ require multi-class struggles far broader than agrarian or rural struggles. Nevertheless, agrarian movements may be able to make strategic contributions to these social struggles. We now turn to an abbreviated discussion of each of these spheres.

First, where wealth and the means of production to create wealth are monopolized by a few (veering towards the obscene 1-99\% ratio), wealth and power redistribution becomes urgent and fundamental. In the context of agrarian societies, this includes redistribution of access to and control of the key means of production-land, water, seas, and forests-thus contesting the very essence of capitalism. Second, where social exclusion, marginalization, and discrimination by one dominant social group over other groups constitute an oppressive social complex layered with xenophobia, racism, misogyny, and so on, social struggles for recognition become an important struggle that can expose the fundamentally regressive nature of right-wing populism. In agrarian societies, this can entail recognition of the rights of indigenous peoples or ethnic minorities over their territory or women's rights to their distinct access and control of the means of production: land, water, and forests. Third, where people have lost their land, territory, houses, savings, pensions, and other important means of production and reproduction because of corporate resource grabs or have lost health care because of scams by financial swindlers, ${ }^{33}$ social struggles for restitution become a key front. In many rural areas, this means restitution of access to land, territory, water, forests, especially in light of global land grabbing during the past decade. Fourth, ecological and climate crisis is one of the hallmarks of the contemporary period in world history; it has deep roots in the history of capitalism, captured by the term Capitalocene (Moore, 2017). Social struggles for ecological regeneration and environmental justice have become an integral part of broader social justice struggles, as Martinez-Alier, Temper, Del Bene, and Scheidel (2016) argue. This connects with what Patel and Moore (2017, p. 43) call "reparation ecology," with struggles for agroecological farming systems (Rosset \& Altieri, 2018), or with struggles for "agrarian climate justice" (Borras \& Franco, 2018). Fifth, these four goals of deep social reforms can only be accomplished through fierce, relentless, and disruptive resistance within and/or against capitalism-which really means political revolution. This puts agrarian movements directly in confrontation with right-wing populist groups, the latter being generally believers, champions, defenders, or apologists of capitalism.

Political actions around these five social reform agendas could expose the contradictory ideological positions between social justice movements and right-wing populism and could contribute to progressively undermining the latter. Right-wing populists are unlikely to meet the social justice-oriented demands of the people because, ultimately, their basic interests fundamentally clash with the people's demands. Vanaik (2018) reminds us, for example, that basic agrarian issues (land, food, rural jobs) render Modi politically vulnerable. The 5Rs discussed above are not

\footnotetext{
${ }^{31}$ The discussion on the 5 Rs draws from a long history of my work on land politics in collaboration with several colleagues and comrades but most especially with Jennifer Franco. This work started with a focus on redistribution and recognition, which are basically direct and logical extensions of struggles for land and territory; more recently, especially informed by our work on land grabs and expulsions, the inseparable issue of "restoration" of resource access or "restitution" has been added-thus, 3Rs. In the last few years, our research work has been devoted to the intersection between climate change politics (mitigation and adaptation) and land grabbing, leading to the addition of the "regeneration" angle. The discussion and inclusion here of "resistance" is in dialogue with Nancy Fraser's work on "redistribution," "recognition," and "representation" (Fraser \& Honneth, 2003). For the progression of our work on this, see Franco, Monsalve, and Borras (2015) and Borras and Franco (2018). Patel and Moore (2017, pp. 207-212) put forward a similar proposition for five Rsrecognition, reparation, redistribution, reimagination, and recreation-where individually and collectively some of these overlap with the 5 Rs in the current paper.

${ }^{32}$ Similarly, some groups may be opposed not to the fundamentals of capitalism but only to some versions of capitalism, such as neoliberal capitalism.

${ }^{33}$ Harvey's broadly cast "accumulation by dispossession" comes to mind (Harvey, 2003).
} 
to be treated like a checklist from which one can cherry pick. The 5 Rs are linked in their logic because they are responding to inherently interconnected social processes. These processes can be highlighted in two abbreviated illustrations.

On the one hand, contemporary capitalism has seized the opportunity to make profit out of responses to climate change via market-based transactions such as carbon sequestration and trading, biofuels, and neoliberal nature conservation. In essence, this is regeneration by dispossession-defined here as the capitalist project of operating within and regenerating nature by dispossessing ordinary villagers to facilitate continuous capital accumulation. Many of the conservation initiatives associated with climate change politics are associated, in varying degrees, with this strategy. Alternative ways to confront regeneration by dispossession are through regeneration by restitution, or regeneration by recognition, or regeneration by redistribution, or a combination of all of these, in the context explained above (see also Borras \& Franco, 2018).

On the other hand, redistribution without transformation represents the prepopulist agitation period, the elitist "business as usual" era. The various forms of redistribution that did occur-usually concessions resulting from social struggles, such as partial land redistribution-were ultimately carried out within a hostile neoliberal system so that any initial gains were easily cancelled out. Many land reforms in the past (both prior to and during neoliberalism) suffered the same fate: small-scale farmer beneficiaries lost out within a broadly neoliberal agricultural policy climate. Some redistributive reforms provoked tensions around issues related to identity politics, such as the recognition claims by indigenous peoples or women that were undermined by (or completely absent from) conventional land reforms. All these have contributed to the accumulation of frustration among ordinary people, many of whom have turned to support right-wing populists. The struggle against right-wing populism can be partly fought by pursuing struggles for redistribution that dovetail with further reforms: thus, redistribution with transformation, redistribution with recognition, or a combination of these (see Borras \& Franco, 2018).

If we take a closer look at the $5 \mathrm{Rs}$, we can begin to understand how their logics are intertwined, how their failure (separately and collectively) under past conditions fed into the right-wing populist "politics of appearances," but at the same time, how they contain the potential to subvert right-wing populism. Middle-of-the-road, social democratic type reformers have shied away from big and insurgent reforms, justifying themselves by arguing that these are undoable, that is, impossible. We must not forget that most of the rights and freedoms that many of us enjoy today, such as the 8-hour working day, maternity leave, minimum wage laws, voting rights, civil rights, the formal end of apartheid in South Africa, and so on, were big and insurgent issues in their own settings and historical moment and seemed impossible-until the political momentum in their favour overruled any conservatism, scepticism, or pessimism.

\section{I CONCLUDING DISCUSSION: TOWARD A CLASS-CONSCIOUS LEFT- WING POPULISM}

Errejón (2016, p. 67) argues that right-wing populism "has been able to recuperate the powerful idea 'community'that we must build a spirit of community at a time when there is more insecurity, more anxiety and fear, more uncertainty about tomorrow." What is being emphasized here is that confronting right-wing populism should start with a good grasp of how and why right-wing populists have been effective in what they are doing. In the context of contemporary right-wing populism, Errejón (2016, p. 68) laments that there is a mistaken assumption that populist methods of work "could be paving the way for [right-wing populist] ideas." He disagrees, "it helps [right-wing populism] much more if we abandon all forms of collective affects [i.e. 'passion'], and thus cede this space to them." Mouffe (2016, p. 124) insists on "reappropriating the term populism." She goes on, "That it is being used in a derogatory way by parties who defend the status quo is no reason to abandon it. It's necessary to reclaim it...and to give it a positive meaning with the notion of 'left-wing populism?."

A priori dismissal of agrarian populism as class blind, naively and romantically allocating everyone a seat at the table is a classic case of a straw person argument because such a populism does not exist. Populism as defined 
and discussed so far inherently includes groups of people across classes-and by the same token, and dialectically, it inherently excludes groups of people. The inclusion-exclusion process of "othering" does not give a seat to everyone at the table. Progressive agrarian populism, in generic terms, is similar to Leninist or Maoist notions of a "broad united front," or indeed, Mao's "mass line" which is, arguably, essentially a form of populism; significantly different but fundamentally similar in the sense that both are attempts at aggregating varying, and even competing, social class and group interests (see Mao, 1975). As Shanin (1983b, p. 270) reminds us, "Russian populists did produce a class analysis, if a different one from that of Engels, i.e. concluding that unlike France of 1848, or of 1871, the main forces due to face each other in Russia are the state and a state-bred squiredom and capitalists versus the 'labouring class,' i.e. a plebeian front of peasants, workers and intelligentsia, allied with the radical soldiers." Finally, perhaps most of the peasant movements studied by Eric Wolf, with special reference to the agency of the middle peasantry, may, to some degree, qualify in the category of agrarian populism (Wolf, 1969). The flip side of this is that only the agrarian movements under the tight command of dogmatic strands of "workerist" Leninist parties could not be accused of populism in the latter's pejorative meaning. Theoretically, this is questionable; politically, it is problematic because this type of agrarian movement does not constitute a significant global force today.

The use of the term working people seemed to be generally acceptable to most Marxists, sometimes to denote the basic "worker-peasant alliance," but as Shivji (2017) argues, it is poorly elaborated. Shivji himself elaborates on the concrete basis underlying the concept of working people, especially in the context of neoliberalism-an explanation that largely overlaps with Bernstein's (2010) notion of "classes of labour":

Commodification and privatization of health care, education, water, sanitation and removal of subsidies from essential foods which all formed part of the social wage goods previously means that now the poor have either to pay for it or go without. All in all, the materiality which underlies producers-peasants and pastoralists, proletarians and semi-proletarians, street hawkers selling consumer goods and peddlers selling cooked food, operators and repairers in backyard workshops-in virtually all sectors is the minimizing of their necessary consumption and maximizing their labour....This is then the material basis common to all sectors of what I called the working people. (Shivji, 2017, p. 11)

Shivji's elaboration on the notion of working people and Bernstein's classes of labour are important conceptual bases for an idea of "class-based populism," or "class struggles with populist consciousness or sensitivities," or indeed class-conscious left-wing populism. Each of these formulations can be described as a contradiction in terms, highlighting concrete contradictions that are partly reflective of the current conditions of the peasantry, working class, and precarious section of the middle class. This, in turn, impacts political agency and agrarian politics in various ways, as well as how we understand these (Bernstein, 2010; chapter 8; Moyo \& Yeros, 2005). Shivji's argument is relevant in this context; he claims that working people "is a 'class' against capital and has great potency in political discourse and mobilization. ...I believe politically, and even conceptually, the term working people has greater potency and validity than worker-peasant alliance." He elaborates, "only real life struggles against the neoliberal phase of capitalist imperialism will help us further to theorize the concept of working people" (Shivji, 2017, p. 12, original emphasis). ${ }^{34}$ The notions of classes of labour and working people can partly explain the rise both of left-wing populist groups (Podemos in Spain, Syriza in Greece-before all the internal problems in both parties had erupted) and of right-wing populist groups who are able to conjure a community of such classes of labour or working people using language that is emotive and dramatic: "the left-behind," "the pushed aside," "the forgotten," and so on.

Two further concepts warrant elaboration, namely, socialism and revolution. If the problem is capitalism, it becomes inconceivable to find a positive future within it because capitalism is a system that is fundamentally based

\footnotetext{
${ }^{34}$ It is in the context of the current fragmentation of classes of labour (in Bernstein's framing) and of Shivji's working people-amid the rise of various forms of populism-that we also need to take seriously the condition and politics of intersectionality. As Bernstein (2010, p. 115, original emphasis) reminds us: "class relations are universal but not exclusive 'determinations' of social practices in capitalism. They intersect and combine with other social differences and divisions, of which gender is the most widespread and which can also include oppressive and exclusionary relations of race and ethnicity, religion and caste."
} 
on exploitation, oppression, and greed (i.e., profit making). This brings us back to socialism-defined here in the broadest sense as per Wright (mentioned at the beginning of this paper). The immediate and most difficult challenge we face here is similar to the problem of reclaiming populism in the context of agrarian politics: "Socialism" is a term that comes with a lot of baggage. It is a proposition that is passionately contested and debated, where each strand of proposition will surely disappoint many. Aware of this, but needing a reference point for the purpose of this paper, I find Wright's proposition for a socialist alternative in the current context helpful. He framed his socialist agenda within a three-pronged strategy of struggles within and against capitalism, namely, ruptural (new emancipatory institutions via a sharp break with existing institutions and social structures; closely associated with revolutionary socialism), interstitial (building new forms of social empowerment in the niches and margins of capitalist society; associated with some strands of anarchism), and symbiotic (using "the state to extend and deepen the institutional forms of social empowerment in ways which also solve certain practical problems faced by dominant classes and elites," closely associated with social democracy; Wright, 2016, pp. 100-101). This is useful for the argument being developed in this paper in at least two ways: (a) the agenda is wide enough to accommodate different anti-capitalist progressive social forces and (b) the institutional, organizational, and political forms and requirements are broad enough to allow for various strands of anti-capitalist and potentially prosocialist forces (or at least those who are not opposed to socialism or not opposed to forging alliance with socialists) to converge. As Wright suggests, "the framework proposed here for a socialism rooted in social empowerment involves a commitment to institutional pluralism and heterogeneity" (2016, p. 104, emphasis added). If we take this framework and we look at the range of ideologically diverse large transnational movements like the La Via Campesina, we can see how such a space can accommodate (to a significant, if not full, extent) the plurality of progressive movements willing and able to identify with a broadly cast socialist agenda and how it can contribute political resource to such a political project-long-term and short-term goals in the struggles within and/or against capitalism-depending on their capacity and ideological orientation.

The deep social reforms explored earlier around the 5Rs and the social forces required to struggle for such reforms can be located within and be made to serve Wright's proposed framework and three-pronged strategy for socialism. Moreover, this is a kind of socialism and strategy around which a broad mass base can be rallied, from the conventional left to anarchist groups, including contemporary antifa groupings and degrowth advocates, from Sanders' typical supporters among the millennials and precarious middle class to the multitude of hard-up classes and sectors that formed the base and supporters of arguably left-wing populist political parties like Podemos in Spain, from radical agrarian movements to urban food justice activists, from radical feminists to climate justice activists, from indigenous peoples' emancipatory movements to progressive race political activists.

The conventional left's notion of a "vanguard party" or "corps of cadres" to lead mass movements is unlikely to be effective as a spearhead even though the current situation could benefit from reinvigorated left political parties. Nor is Mao's idea of armed struggle as the principal form of struggle, subordinating all other forms of mass movements, likely to be able to provide an overarching strategy and form of struggle. As Wainwright (2018) reminds us, those working from this tradition will have to seriously rethink how to forge productive conversations with those who subscribe to other traditions, for example, the ideas of anarchism and its stance on antiauthoritarianism and anticentralism (Bookchin, 2015; Springer, 2015; see also Roman-Alcalá, 2018), the growing advocacy and movement around the idea of degrowth (Boillat, Gerber, \& Funes-Monzote, 2012; Kallis, 2017; Roman-Alcalá, 2017), feminist (Harcourt \& Nelson, 2015) and race politics (White, 2017), and so on-keeping in mind that socialist and communist parties' historical track record of engaging with such advocacies and movements has been checkered at best. ${ }^{35} \mathrm{How}^{-}$ ever, and conversely, without the participation of conventional left-wing communist and socialist parties, the various groupings of non-political party radical movements and initiatives are unlikely to get closer to their goals of transformative social change, as many major waves of such initiatives in the recent past, such as the Occupy Wall Street, have shown. The key is to explore and harness potential synergy among these disparate democratic challengers is less

\footnotetext{
${ }^{35}$ For those working in the context and tradition of communist and socialist party work, Rosa Luxemburg's earlier ideas of a "mass party" and "mass strike" and Antonio Gramsci's notion of "organic intellectuals" may have renewed relevance and traction and are worth serious revisiting.
} 
about determining which specific political line or idea is superior and thus could be the spearhead, than about determining and building the basis for a pluralist platform that could bring such diverse groups to a common political project -however daunting a task that might appear.

The greatest challenge may prove to be how to sustain the initial mild interest in-or at least the non-resistance to -socialism of the types espoused by Sanders' supporters, the agrarian and food sovereignty movements, and the broad environmental and climate justice activist circles, many of which may not have been sensitized to and significantly engaged in socialist politics despite their deep anti-capitalist sentiments. Given that Sanders managed to boldly put forward an openly socialist agenda to be carried out through a political revolution in the context of the United States in the early 21st century, and because of millions of people across the middle class and working class and across the race, gender, and generational divides came on board, energized, and animated, a broader international conversation and political project explicitly framed within socialism becomes feasible-and so too the vehicle to achieve it, political revolution. The term is used here in a similar way as it is used by Sanders: "a deep commitment against the anti-subversive petty reform incrementalism promoted by social forces behind the 'consensus at the centre'." This task represents a difficult challenge partly because the justifications, mechanisms, and processes of the "petty reform incrementalism" have been routinized and normalized to the point that they invisibilize what is wrong with, or disqualify serious interrogation of, this approach and the many issues that matter to people.

Combining class politics and populism is desirable despite the tension and contradictions that such an intersection necessarily internalizes. What is promising, along this line, is an enriched and reinvigorated left-wing populism, that is, anti-capitalist in character, socialist in orientation, pluralist in ideological orientation, heterogeneous in institutional platforms, and fundamentally founded on an alliance between the classes of labour or working people (which necessarily includes the various strata of the peasantry and proletariat) and the precarious strata of the middle class or petty bourgeoisie, and their overlapping social groupings based on multiple "identifiers," including community, gender, race, ethnicity, generation, and religion. This form of populism is very different from an essentially identity-based populism where class is altogether absent or is deliberately negated, a mere footnote, or an afterthought, addressed only if and when it is referenced.

This reclaiming and reformulation constitutes a sharp rebuke of certain problematic populisms in the agrarian tradition. Iconic examples include some Indian populist peasant movements (Assadi, 1994; Brass, 1994, 1995). The problem with these types of movements is not that they are class blind because, arguably, they are not. The problem is their consciousness of the antagonistic class interests that exist, and their deliberate effort to downplay or cover-up the tensions and contradictions within a movement or political agitation to create a single discourse under the dominant class-that is rich peasant-banner. When such peasant movements consciously block rural working class issues such as land reform, landless labourer's work and wage issues, and so on, from getting onto the agenda of populist mobilizations, and instead narrowly focus on "fairer" (always meaning "higher") prices for their produce, defence of the private property regime, and so on, they acquire a conservative character (Brass, 1994, 1995; Pattenden, 2005). This is not a naïve type of agrarian populism; it is a consciously reactionary type of populism. Yet most contemporary agrarian and food sovereignty movements do not share this type of reactionary agrarian populism.

Finally, a tradition that comes from class-based movements has become more urgent and necessary than ever, namely, an internationalist perspective. The emergence of Bernstein's 'classes of labour' or Shivji's working people is a global phenomenon. The issues that are addressed by all strands of populism are not confined to a national territory; they are international and are inserted into the dynamics of global capitalism. Anti-capitalist struggles are to be fought within national territories and internationally. Food sovereignty movements have actual and potential contributions to make, albeit unevenly across space and over time, to struggles that are (sub)national with an international perspective and international with (sub)national roots. Internationalism can be a counterweight to the xenophobic nationalism of right-wing populist agitations. An internationalist perspective takes as its starting point that social class and other identity struggles are fought in local communities, but that solidarity struggles are necessary, and necessarily cross-border in character, because of the international interconnection of the causes, conditions, and consequences of the multiple crises caused by capitalism. 
I conclude this essay by going back to Henry Bernstein's appeal for Marxist political economists to take agrarian politics and agrarian populism seriously, dovetailing this appeal with a recent observation by Michael Levien, Michael Watts and Yan Hairong (2018, p. 853): "While Marxists have long criticized 'populists' for ignoring capitalism and class, populists have charged Marxists with an obsessive concern with accumulation and class, an insensitivity to the contingencies of history and various blindspots regarding gender and identity." They conclude,

On the one hand, more 'populist' scholarship - whether focused on land grabs, food sovereignty or land reform - has far more explicitly incorporated Marxian insights about class and the dynamics of capitalism than ever before. On the other hand, much explicitly Marxian scholarship has moved away from its dismissal of peasant political agency; the hyper-structuralism of modes of production debates; and linear or Eurocentric conceptions of history embedded in the transition problematic and 'doomed peasant dogma'. (ibid., p. 854)

This intellectual and political reciprocity does not undermine the fundamental standpoint of each camp. Teodor Shanin observed the process between the People's Will intellectuals and Marx, how each treated the other seriously and how each was willing to concede some important elements in their perspective: "That does not make Marx into a populist or turn members of the People's Will into crypto-marxists. They were political allies, who supported and influenced each other" (Shanin, 1983b, p. 268). Indeed, such a productive encounter is urgently needed in building and reinforcing an agenda for political conversation around the notion of a reconstituted, class-conscious, left-wing populism in order to defeat right-wing populism and to pave a path toward a possible socialist future.

\section{ACKNOWLEDGEMENTS}

This paper draws on discussions over many years with comrades in the Philippine left movement, especially Steve Quiambao, Jennifer C. Franco, and Danny Carranza, and with comrades in the La Via Campesina and Transnational Institute (TNI) and, in recent years, with colleagues in the ERPI collective and fellow researchers at the ISS, for which I am deeply grateful. I would like to thank Haroon Akram-Lodhi, Alberto Alonso-Fradejas, Henry Bernstein, Daniela Calmon, Ben Cousins, Marc Edelman, Harriet Friedmann, Burak Gurel, Ruth Hall, Francis Isaac, Cris Kay, Michael Levien, Lyda Forero, Jaume Franquesa, Ben Luig, Natalia Mamonova, Phil McMichael, Sofia Monsalve, Antonio Roman-Alcala, lan Scoones, Amod Shah, Teodor Shanin, Annie Shattuck, Tony Weis, Ben White, and Wendy Wolford for various comments on earlier drafts, most of which were very critical, some of which were just a few lines of encouragement but all of which have the overall effect of reaffirming the relevance of pursuing this paper. I also thank the JAC editors for their encouragement and support, and the two anonymous reviewers for critical but very helpful comments and suggestions. Their feedback saved the paper from embarrassing mistakes, awkward formulations, and ridiculous propositions and helped improve the level of clarity of its propositions. But still, many of the questions and comments raised by several colleagues regarding various elements of this paper remain unaddressed -not because I decided to ignore these questions and suggestions but because I myself do not know the answers or how to respond at the moment. I would also like to thank the organizers of and participants in the Finnish Society for Development Research (FSDR) conference on February 15-16, 2018 at the University of Helsinki, especially Barry Gills, Bon Juego, and Jesse Ribot, for their comments on the presentation that was based on this paper. Various parts of the paper have been presented at several other international conferences where I greatly benefited from useful feedback and comments from the organizers and participants: University of Bern's Centre for Development and Environment (CDE) in October 2017, University of Indonesia in September 2017, University of North Sumatra in December 2017, Utrecht University in December 2017, and Max Planck Institute in Halle (Germany) in May 2018. I would like to thank Ben Luig of the Rosa Luxemburg Foundation for suggesting that I write a short note on "authoritarian populism and food sovereignty." Without Ben's request, I would not have thought of embarking on this task, the final outcome of which is this long essay, which is a preliminary outline of an ongoing attempt at making sense of how to understand-and defeat-contemporary right-wing populism from the perspective of the 
rural world. Finally, I thank Paula Bownas for her excellent copyediting assistance. All remaining errors and shortcomings are mine alone. This paper is dedicated to the memory of comrade Gani Serrano.

\section{ORCID}

Saturnino M. Borras Jr. (D) https://orcid.org/0000-0002-2719-4154

\section{REFERENCES}

Adaman, F., Arsel, M., \& Akbulut, B. Forthcoming(2019). Neoliberal developmentalism, authoritarian populism, and extractivism in the countryside: The Soma mining disaster in Turkey. Journal of Peasant Studies.

Akram-Lodhi, A. H. (2018). The promise? Using and misusing authoritarian populism. Paper presented at the ERPI 2018 International Conference Authoritarian Populism and the Rural World, Conference Paper No.6. March 2018, International Institute of Social Studies, The Hague.

Akram-Lodhi, A. H., \& Kay, C. (2010a). Surveying the agrarian question (part 1): Unearthing foundations, exploring diversity. Journal of Peasant Studies, 37(1), 177-202. https://doi.org/10.1080/03066150903498838

Akram-Lodhi, A. H., \& Kay, C. (2010b). Surveying the agrarian question (part 2): Current debates and beyond. Journal of Peasant Studies, 37(2), 255-284. https://doi.org/10.1080/03066151003594906

Alinsky, S. (1971). Rules for radicals: A pragmatic primer for realistic radicals. New York: Vintage.

Anderson, P. (2019). Bolsonaro's Brazil. London Review of Books, 41(3), 11-22.

Andrade, D. (2019). Populism from above and below: Agriculture and the political ambiguities of the Workers' Party in Brazil. ERPI Working Paper Series \# 83. The Hague: International Institute of Social Studies; see also Emancipatory Rural Politics Initiative (www.iss.nl/erpi).

Arsel, M., Hogenboom, B., \& Pellegrini, L. (2016). The extractive imperative in Latin America. The Extractive Industries and Society, 3(4), 880-887. https://doi.org/10.1016/j.exis.2016.10.014

Assadi, M. (1994). 'Khadi curtain', 'weak capitalism' and 'Operation Ryot': Some ambiguities in farmers' discourse, Karnataka and Maharashtra 1980-93. Journal of Peasant Studies, 21(3-4), 212-227. https://doi.org/10.1080/ 03066159408438560

Baud, J. M., \& Rutten, R. A. (Eds.) (2004). Popular intellectuals and social movements: Framing protest in Asia, Africa, and Latin America. Cambridge: Cambridge University Press.

Baviskar, A. (1999). In the belly of the river: Tribal conflicts over development in the Narmada Valley. Oxford: Oxford University Press.

Bello, W. (2018). Counterrevolution, the countryside and the middle classes: Lessons from five countries. Journal of Peasant Studies, 45(1), 21-58. https://doi.org/10.1080/03066150.2017.1380628

Bernstein, H. (2010). Class dynamics of agrarian change. Halifax: Fernwood.

Bernstein, H. (2018). The 'peasant problem'in the Russian revolution(s), 1905-1929. Journal of Peasant Studies, 45(5-6), 1127-1150. https://doi.org/10.1080/03066150.2018.1428189

Bernstein, H., Friedmann, H., van der Ploeg, J. D., Shanin, T., \& White, B. (2018). Fifty years of debate on peasantries, 1966-2016. Journal of Peasant Studies, 45(4), 689-714. https://doi.org/10.1080/03066150.2018.1439932

Boillat, S., Gerber, J. F., \& Funes-Monzote, F. R. (2012). What economic democracy for degrowth? Some comments on the contribution of socialist models and Cuban agroecology. Futures, 44(6), 600-607. https://doi.org/10.1016/j. futures.2012.03.021

Bond, B., \& Exley, Z. (2016). Rules for revolutionaries: How big organizing can change everything. White River Junction, VT: Chelsea Green.

Bookchin, M. (2015). The next revolution: Popular assemblies and the promise of direct democracy. New York: Verso.

Borras, S. M. (2007). Pro-poor land reform: A critique. Ottawa: University of Ottawa Press.

Borras, S. M., \& Franco, J. C. (2009). Transnational agrarian movements struggling for land and citizenship rights. IDS Working Papers, 2009(323). Brighton: University of Sussex, Institute of Development Studies.

Borras, S. M., \& Franco, J. C. (2018). The challenge of locating land-based climate change mitigation and adaptation politics within a social justice perspective: Towards an idea of agrarian climate justice. Third World Quarterly, 39(7), $1308-1325$. https://doi.org/10.1080/01436597.2018.1460592

Borras, S. M., Moreda, T., Alonso-Fradejas, A., \& Brent, Z. (2018). Converging social justice issues and movements: Implications for political actions and research. Third World Quarterly, 39(7), 1227-1246. https://doi.org/10.1080/ 01436597.2018.1491301 
Brass, T. (1994). Post-script: Populism, peasants and intellectuals, or what's left of the future? Journal of Peasant Studies, 21(3-4), 246-286. https://doi.org/10.1080/03066159408438562

Brass, T. (Ed.) (1995). New farmers' movements in India. London: Frank Cass.

Brass, T. (1997). The agrarian myth, the 'new' populism and the 'new' right. Journal of Peasant Studies, 24(4), $201-245$. https://doi.org/10.1080/03066159708438649

Brent, Z. W., Schiavoni, C. M., \& Alonso-Fradejas, A. (2015). Contextualising food sovereignty: The politics of convergence among movements in the USA. Third World Quarterly, 36(3), 618-635. https://doi.org/10.1080/ 01436597.2015 .1023570

Bueza, M. (2018, December 29). Duterte's satisfaction rating rises in Q4 2018 - SWS. Rappler, online, no page number. https://www.rappler.com/nation/219915-duterte-satisfaction-ratings-sws-december-2018; downloaded 10 January 2019.

Byres, T. J. (1979). Of neo-populist pipe-dreams: Daedalus in the Third World and the myth of urban bias. Journal of Peasant Studies, 6(2), 210-244. https://doi.org/10.1080/03066157908438073

Byres, T. J. (2004). Neo-classical neo-populism 25 years on: Déjà vu and déjà passé. Towards a critique. Journal of Agrarian Change, 4(1-2), 17-44. https://doi.org/10.1111/j.1471-0366.2004.00071.x

Chappell, M. J. (2018). Beginning to end hunger: Food and the environment in Belo Horizonte, Brazil, and beyond. Berkeley, CA: University of California Press.

Chayanov, A. V. (1966 [orig. 1925]). In D. Thorner, et al. (Eds.), The theory of the peasant economy. Manchester: Manchester University Press.

Chrisafis, A. (2017, April 21). The real misery is in the countryside: Support for Le Pen surges in rural France. The Guardian, online, no page number. https://www.theguardian.com/world/2017/apr/21/counryside-marine-le-pen-forgottenfrance-presidential-election-2017; downloaded 9 January 2019.

Chrisman, S. (2016). Want to understand Trump's rise? Head to the farm. Civil Eats, 27 October 2016. https://civileats.com/ 2016/10/27/want-to-understand-trumps-rise-head-to-the-farm/; downloaded 5 February 2018.

Claeys, P. (2012). The creation of new rights by the food sovereignty movement: The challenge of institutionalizing subversion. Sociology, 46(5), 844-860.

Claeys, P., \& Delgado Pugley, D. (2017). Peasant and indigenous transnational social movements engaging with climate justice. Canadian Journal of Development Studies, 38(3), 325-340. https://doi.org/10.1080/02255189.2016.1235018

Clapp, J., \& Isakson, S. R. (2018). Speculative harvests: Financialization, food, and agriculture. Halifax: Fernwood. London: Practical Action

Clark, P. (2017). Neo-developmentalism and a 'vía campesina' for rural development: Unreconciled projects in Ecuador's Citizen's Revolution. Journal of Agrarian Change, 17(2), 348-364. https://doi.org/10.1111/joac.12203

Cousins, B., Dubb, A., Hornby, D., \& Mtero, F. (2018). Social reproduction of 'classes of labour' in the rural areas of South Africa: Contradictions and contestations. Journal of Peasant Studies, 45(5-6), 1060-1085. https://doi.org/10.1080/ 03066150.2018 .1482876

Curato, N. (Ed.) (2017). A Duterte reader: Critical essays on Rodrigo Duterte's early presidency. Manila: Ateneo de Manila vUniversity Press.

De Schutter, O. (2014). UN Special Rapporteur on the right to food. Report on agroecology and the right to food. Geneva: Human Rights Council.

Desmarais, A. (2007). La Via Campesina: Globalization and the power of peasants. Halifax: Fernwood.

Docena, H. (2018). The rise of populist authoritarianisms in Asia: Challenges for peoples' movements. Bangkok: Focus on the Global South.

Edelman, M. (1999). Peasants against globalization: Rural social movements in Costa Rica. Stanford, CA: Stanford University Press.

Edelman, M. (2018). Sacrifice zones in rural and non-metro USA: Fertile soil for authoritarian populism. OpenDemocracy blog entry: https://www.opendemocracy.net/marc-edelman/sacrifice-zones-in-rural-and-non-metro-usa-fertile-soil-forauthoritarian-populism; downloaded 19 February 2018.

Edelman, M., \& Borras, S. M. (2016). Political dynamics of transnational agrarian movements. Halifax: Fernwood. Rugby, UK: Practical Action Publishing

Edelman, M., Weis, T., Baviskar, A., Borras, S. M., Holt-Giménez, E., Kandiyoti, D., \& Wolford, W. (2014). Introduction: Critical perspectives on food sovereignty. Journal of Peasant Studies, 41(6), 911-931. https://doi.org/10.1080/ 03066150.2014 .963568 
Engels, F. (1894). Peasant Question in France and Germany. https://www.marxists.org/archive/marx/works/1894/peasantquestion/index.htm; downloaded 11 February 2019.

Errejón, I. (2016). Podemos: In the name of the people. In I. Errejón, \& C. Mouffe (Eds.), Errejón in conversation with Mouffe. London: Lawrence and Wishart.

Fairbairn, M. (2014). 'Like gold with yield': Evolving intersections between farmland and finance. Journal of Peasant Studies, 41(5), 777-795. https://doi.org/10.1080/03066150.2013.873977

Ferguson, J. (2015). Give a man a fish: Reflection on the new politics of distribution. Durham, NC: Duke University Press.

Fox, J. (Ed.) (1990). The challenge of rural democratization. London: Frank Cass.

Fox, J. (2007). Accountability politics: Power and voice in rural Mexico. New York: Oxford University Press.

Franco, J. C. (2011). Bound by law: Filipino rural poor and the search for justice in a plural-legal landscape. Manila: Ateneo de Manila University Press.

Franco, J. C. (2014). Reclaiming Free Prior and Informed Consent (FPIC) in the context of global land grabs. Amsterdam: Transnational Institute (TNI).

Franco, J. C., \& Borras, S. M. (2009). Paradigm shift: The 'September Thesis' and rebirth of the 'Open' peasant mass movement in the era of neoliberal globalization in the Philippines. In D. Caouette, \& S. Turner (Eds.), Agrarian angst and rural resistance in contemporary Southeast Asia (pp. 226-246). London: Routledge.

Franco, J. C., Monsalve, S., \& Borras, S. M. (2015). Democratic land control and human rights. Current Opinion in Environmental Sustainability, 15, 66-71. https://doi.org/10.1016/j.cosust.2015.08.010

Franquesa, J. (2019). The vanishing exception: Republican and reactionary specters of populism in rural Spain. Journal of Peasant Studies, forthcoming.

Franz, C., Fratzscher, M. F., \& Kritikos, A. S. (2018). German right-wing party AfD finds more support in rural areas with aging populations. DIW Weekly Report 7+8 2018. Berlin: DIW Berlin.

Fraser, N., \& Honneth, A. (2003). Redistribution or recognition? A political-philosophical exchange. New York: Verso.

Gaventa, J. (1982). Power and powerlessness: Quiescence and rebellion in an Appalachian valley. Champaign, IL: University of Illinois Press.

Gaventa, J. (2006). Finding the spaces for change: A power analysis. IDS Bulletin, 37(6), 23-33. https://doi.org/10.1111/ j.1759-5436.2006.tb00320.x

Gerber, J. F. (2014). The role of rural indebtedness in the evolution of capitalism. Journal of Peasant Studies, 41(5), 729-747. https://doi.org/10.1080/03066150.2014.921618

Giunta, I. (2014). Food sovereignty in Ecuador: Peasant struggles and the challenge of institutionalization. Journal of Peasant Studies, 41(6), 1201-1224. https://doi.org/10.1080/03066150.2014.938057

Griffin, K., Khan, A. R., \& Ickowitz, A. (2002). Poverty and the distribution of land. Journal of Agrarian Change, 2(3), 279-330. https://doi.org/10.1111/1471-0366.00036

Gudynas, E. (2011). Buen Vivir: Today's tomorrow. Development, 54(4), 441-447. https://doi.org/10.1057/dev.2011.86

Gurel, B., Kucuk, B., \& Tas, S. Forthcoming(2019). The rural roots of the rise of the Justice and Development Party in Turkey. Journal of Peasant Studies, 1-23. https://doi.org/10.1080/03066150.2018.1552264

Hadiz, V. (2016). Islamic populism in Indonesia and the Middle East. Cambridge: Cambridge University Press.

Hall, R. (2011). Land grabbing in Southern Africa: The many faces of the investor rush. Review of African Political Economy, 38(128), 193-214. https://doi.org/10.1080/03056244.2011.582753

Hall, S. (1985). Authoritarian populism: A reply. New Left Review, 151, 115-124.

Harcourt, W., \& Nelson, I. (Eds.) (2015). Practising feminist political ecologies: Moving beyond the 'green economy'. London: Zed Books.

Harvey, D. (2003). The new imperialism. New York: Oxford University Press.

Henderson, T. P. (2018). The class dynamics of food sovereignty in Mexico and Ecuador. Journal of Agrarian Change, 18(1), 3-21. https://doi.org/10.1111/joac.12156

Hobsbawm, E. (1987). The age of empire, 1875-1914. London: Abacus.

Holt-Giménez, E. (2017). A foodie's guide to capitalism: Understanding the political economy of what we eat. New York: Monthly Review Press. Oakland, CA: Food First

Holt-Giménez, E., \& Shattuck, A. (2011). Food crises, food regimes and food movements: Rumblings of reform or tides of transformation? Journal of Peasant Studies, 38(1), 109-144. https://doi.org/10.1080/03066150.2010.538578

Huizer, G. (1975). How peasants become revolutionaries: Some cases from Latin America and Southeast Asia. Development and Change, 6(3), 27-56. https://doi.org/10.1111/j.1467-7660.1975.tb00682.x 
Isakson, S. R. (2014). Maize diversity and the political economy of agrarian restructuring in Guatemala. Journal of Agrarian Change, 14(3), 347-379. https://doi.org/10.1111/joac.12023

Jones, S. (2018, December 3). Far right wins seats in Spanish region for first time since Franco. The Guardian, online, no page number. https://www.theguardian.com/world/2018/dec/03/spain-far-right-vox-party-wins-seats-in-andalucia-for-firsttime-since-franco; downloaded 10 January 2019.

Kallis, G. (2017). Socialism without growth. Capitalism Nature Socialism, 1-18. https://doi.org/10.1080/ 10455752.2017.1386695

Kautsky, K. (1988 [orig. 1899]). The agrarian question (Vol. 1). London: Zwan.

Kay, C. (2009). Development strategies and rural development: Exploring synergies, eradicating poverty. Journal of Peasant Studies, 36(1), 103-137. https://doi.org/10.1080/03066150902820339

Khadse, A., Rosset, P., Morales, H., \& Ferguson, B. (2018). Taking agroecology to scale: The Zero Budget Natural Farming peasant movement in Karnataka, India. Journal of Peasant Studies, 45(1), 192-219. https://doi.org/10.1080/ 03066150.2016 .1276450

Kurtzleben, D. (2016, November 14). Rural voters played a big part in helping Trump defeat Clinton. National Public Radio: https://www.npr.org/2016/11/14/501737150/rural-voters-played-a-big-part-in-helping-trump-defeat-clinton; downloaded 9 January 2019.

Laclau, E. (2005). On populist reason. London: Verso.

Lenin, V. I. (2004 [orig. 1905]). Development of capitalism in Russia. Honolulu, HI: University Press of the Pacific.

Lerche, J., \& Shah, A. (2018). Conjugated oppression within contemporary capitalism: Class, caste, tribe and agrarian change in India. Journal of Peasant Studies, 45(5-6), 927-949. https://doi.org/10.1080/03066150.2018.1463217

Levien, M. (2011). Special economic zones and accumulation by dispossession in India. Journal of Agrarian Change, 11(4), 454-483. https://doi.org/10.1111/j.1471-0366.2011.00329.x

Levien, M., Watts, M., \& Yan, H. (2018). Agrarian Marxism. Journal of Peasant Studies, 45(5-6), 853-883. https://doi.org/ 10.1080/03066150.2018.1534101

Li, T. M. (2007). The will to improve: Governmentality, development, and the practice of politics. Durham, NC: Duke University Press. https://doi.org/10.1215/9780822389781

Li, T. M. (2010). To make live or let die? Rural dispossession and the protection of surplus populations. Antipode, 41, 66-93. https://doi.org/10.1111/j.1467-8330.2009.00717.x

Li, T. M. (2011). Centering labor in the land grab debate. Journal of Peasant Studies, 38(2), 281-298. https://doi.org/10.1080/ 03066150.2011.559009

Li, T. M. (2014). Land's end: Capitalist relations on an indigenous frontier. Durham, NC: Duke University Press.

Lipton, M. (1977). Why poor people stay poor: A study of urban bias in world development. London: Temple Smith. Canberra: Australian National University Press

Mamonova, N. (2016). Naive monarchism and rural resistance in contemporary Russia. Rural Sociology, 81(3), 316-342. https://doi.org/10.1111/ruso.12097

Mamonova, N. (2018). Patriotism and food sovereignty: Changes in the social imaginary of small-scale farming in postEuromaidan Ukraine. Sociologia Ruralis, 58(1), 190-212. https://doi.org/10.1111/soru.12188

Mamonova, N. (2019). Understanding the silent majority in authoritarian populism: What can we learn from popular support for Putin in rural Russia? Journal of Peasant Studies, forthcoming.

Mao, T.-T. (1975). Selected works (Vol. II). Peking: Foreign Language Press.

Martinez-Alier, J. (2014). The environmentalism of the poor. Geoforum, 54, 239-241. https://doi.org/10.1016/j. geoforum.2013.04.019

Martinez-Alier, J., Temper, L., Del Bene, D., \& Scheidel, A. (2016). Is there a global environmental justice movement? Journal of Peasant Studies, 43(3), 731-755. https://doi.org/10.1080/03066150.2016.1141198

Martinez-Torres, M. E., \& Rosset, P. M. (2010). La Vía Campesina: The birth and evolution of a transnational social movement. Journal of Peasant Studies, 37(1), 149-175. https://doi.org/10.1080/03066150903498804

Marx, K. (1983 [original 1881]). The reply to Zasulich. In T. Shanin (Ed.), Late Marx and the Russian road (pp. 123-124). London: Routledge and Kegan Paul.

McKay, B., Nehring, R., \& Walsh-Dilley, M. (2014). The 'state' of food sovereignty in Latin America: Political projects and alternative pathways in Venezuela, Ecuador and Bolivia. Journal of Peasant Studies, 41(6), 1175-1200. https://doi.org/ 10.1080/03066150.2014.964217

McKay, B. M. (2017). Agrarian extractivism in Bolivia. World Development, 97, 199-211. https://doi.org/10.1016/j. worlddev.2017.04.007 
McKeon, N. (2018). Are equity and sustainability a likely outcome when foxes and chickens share the same coop? Critiquing the concept of multistakeholder governance of food security. Globalizations, 14(3), 379-398.

McMichael, P. (2008). Peasants make their own history, but not just as they please. Journal of Agrarian Change, 8(2-3), 205-228. https://doi.org/10.1111/j.1471-0366.2008.00168.x

Mills, E. N. (2018). Implicating 'fisheries justice' movements in food and climate politics. Third World Quarterly, 39(7), 1270-1289. https://doi.org/10.1080/01436597.2017.1416288

Monsalve, S. (2013). The human rights framework in contemporary agrarian struggles. Journal of Peasant Studies, 40(1), 239-290.

Moore, B. Jr. (1967). Social origins of dictatorship and democracy: Lord and peasant in the making of the modern world (Vol. 268). Boston, MA: Beacon Press.

Moore, J. W. (2017). The Capitalocene, part I: On the nature and origins of our ecological crisis. Journal of Peasant Studies, 44(3), 594-630. https://doi.org/10.1080/03066150.2016.1235036

Mouffe, C. (2005). The 'end of politics' and the challenge of right-wing populism. In F. Panizza (Ed.), Populism and the mirror of democracy (pp. 50-71). London: Verso.

Mouffe, C. (2016). Podemos: In the name of the people. In I. Errejón, \& C. Mouffe (Eds.), Errejón in conversation with Mouffe. London: Lawrence and Wishart.

Moyo, S., \& Yeros, P. (Eds.) (2005). Reclaiming the land: The resurgence of rural movements in Africa, Asia and Latin America. London: Zed Books.

NES (2014). Statistics: National Election Study 2014. Economic \& Political Weekly, xlix(39), 130-134. Appendix 1

Newell, P., \& Wheeler, J. (Eds.) (2006). Rights, resources and the politics of accountability. London: Zed Books.

Nishizaki, Y. (2014). Peasants and the redshirt movement in Thailand: Some dissenting voices. Journal of Peasant Studies, 41(1), 1-28. https://doi.org/10.1080/03066150.2013.873409

Paige, J. (1975). Agrarian revolutions. New York: Free Press.

Panizza, F. (2005). Introduction: Populism and the mirror of democracy. In F. Panizza (Ed.), Populism and the mirror of democracy (pp. 1-31). London: Verso.

Patel, R. (2009). Food sovereignty. Journal of Peasant Studies, 36(3), 663-706. https://doi.org/10.1080/ 03066150903143079

Patel, R., \& Moore, J. W. (2017). A history of the world in seven cheap things. Berkeley, CA: University of California Press.

Pattenden, J. (2005). Trickle-down solidarity, globalisation and dynamics of social transformation in a south Indian village. Economic and Political Weekly, 40(19), 1975-1985.

Paxton, R. (1997). French peasant fascism: Henry Dorgeres's Greenshirts and the crises of French agriculture, 1929-1939. Oxford: Oxford University Press.

Peluso, N. (1992). Rich forests, poor people: Resource control and resistance in Java. Berkeley and Los Angeles, CA: University of California Press.

Peluso, N. L., \& Lund, C. (2011). New frontiers of land control: Introduction. Journal of Peasant Studies, 38(4), 667-681. https://doi.org/10.1080/03066150.2011.607692

Popkin, S. L. (1979). The rational peasant: The political economy of rural society in Vietnam. Berkeley, CA: University of California Press.

Putzel, J. (1995). Managing the 'main force': The communist party and the peasantry in the Philippines. Journal of Peasant Studies, 22(4), 645-671. https://doi.org/10.1080/03066159508438591

Rancière, J. (2016). The populism that is not to be found. In A. Badiou, et al. (Eds.), What is a people (pp. 100-106). New York: Columbia University Press.

Ribot, J. C. (1999). Decentralisation, participation and accountability in Sahelian forestry: Legal instruments of politicaladministrative control. Africa, 69(1), 23-65. https://doi.org/10.2307/1161076

Ribot, J. C., \& Peluso, N. L. (2003). A theory of access. Rural Sociology, 68(2), 153-181.

Roman-Alcalá, A. (2017). Looking to food sovereignty movements for postgrowth theory. Ephemera, 17(1), 119-145.

Roman-Alcalá, A. (2018). (Relative) autonomism, policy currents and the politics of mobilisation for food sovereignty in the United States: The case of Occupy the Farm. Local Environment, 23(6), 619-634. https://doi.org/10.1080/ 13549839.2018.1456516

Rosset, P., \& Altieri, M. (2018). Politics and science of agroecology. Halifax: Fernwood. London: Practical Action Books

Saad-Filho, A. (2018). Brazil: The collapse of democracy? The Bullet, 27 October. https://socialistproject.ca/2018/10/brazilthe-collapse-of-democracy/; downloaded 1 February 2019. 
Sanders, B. (2016). Our revolution: A future to believe in. New York: Thomas Dunne Books.

Schoenberger, L., Beban, A., \& Lamb, V. (2018). Authoritarian rule shedding its populist skin: How loss of independent media in the 2017 crackdown shapes rural politics in Cambodia. Paper presented at ERPI 2018 International Conference Authoritarian Populism and the Rural World, Conference Paper No.70, International Institute of Social Studies, The Hague.

Scoones, I. (2015). Sustainable livelihoods and rural development. Halifax: Fernwood. Rugby: Practical Action Publishing

Scoones, I., Edelman, M., Borras, S. M., Hall, R., Wolford, W., \& White, B. (2018). Emancipatory rural politics: Confronting authoritarian populism. Journal of Peasant Studies, 45(1), 1-20. https://doi.org/10.1080/03066150.2017.1339693

Scott, J. (1976). The moral economy of the peasant. New Haven, CT: Yale University Press.

Scott, J. C. (1985). Weapons of the weak: Everyday forms of peasant resistance. New Haven, CT: Yale University Press.

Shanin, T. (1972). The awkward class: Political sociology of peasantry in a developing society Russia 1910-1925. London and Oxford: Clarendon Press.

Shanin, T. (1983a). Late Marx: Gods and craftsmen. In T. Shanin (Ed.), Late Marx and the Russian road (pp. 3-39). London: Routledge and Kegan Paul.

Shanin, T. (1983b). Marxism and the vernacular revolutionary traditions. In T. Shanin (Ed.), Late Marx and the Russian road (pp. 243-279). London: Routledge and Kegan Paul.

Shattuck, A., Schiavoni, C. M., \& VanGelder, Z. (2015). Translating the politics of food sovereignty: Digging into contradictions, uncovering new dimensions. Globalizations, 12(4), 421-433. https://doi.org/10.1080/14747731.2015.1041243

Shivji, I. (2017). The concept of 'working people'. Agrarian South: Journal of Political Economy, 6(1), 1-13.

Soriano, C. R. (2015). Strategic activism for democratization and social change. In D. Holtzhausen, \& A. Zerfass (Eds.), The Routledge handbook of strategic communication (pp. 424-438). London: Routledge.

Springer, S. (2015). Postneoliberalism? Review of Radical Political Economics, 47(1), 5-17. https://doi.org/10.1177/ 0486613413518724

Taggart, P. (2000). Populism. Buckingham: Open University Press.

Thompson, E. P. (2013 [orig. 1968]). The making of the English working class. London: Penguin Modern Classics.

Tolkien, J. R. R. (1980). In C. Tolkien (Ed.), Unfinished Tales. London: George Allen \& Unwin.

Tramel, S. (2016). The road through Paris: Climate change, carbon, and the political dynamics of convergence. Globalizations, 13(6), 960-969. https://doi.org/10.1080/14747731.2016.1173376

Tramel, S. (2018). Convergence as political strategy: Social justice movements, natural resources and climate change. Third World Quarterly, 39(7), 1290-1307. https://doi.org/10.1080/01436597.2018.1460196

Tsikata, D., \& Yaro, J. A. (2014). When a good business model is not enough: Land transactions and gendered livelihood prospects in rural Ghana. Feminist Economics, 20(1), 202-226. https://doi.org/10.1080/13545701.2013.866261

Tsing, A. L. (2000). Inside the economy of appearances. Public Culture, 12(1), 115-144. https://doi.org/10.1215/0899236312-1-115

Ulrich-Schad, J. D., \& Duncan, C. M. (2018). People and places left behind: Work, culture and politics in the rural United States. Journal of Peasant Studies, 45(1), 59-79. https://doi.org/10.1080/03066150.2017.1410702

van der Ploeg, J. D. (2013). Peasants and the art of farming: A Chayanovian manifesto. Halifax: Fernwood Publishing.

van der Ploeg, J. D. (2018). Differentiation: Old controversies, new insights. Journal of Peasant Studies, 45(3), 489-524. https://doi.org/10.1080/03066150.2017.1337748

Vanaik, A. (2017a). The rise of Hindu authoritarianism: Secular claims, communal realities. London: Verso.

Vanaik, A. (2017b). Hindutva's forward march. Jacobin, September 2017. https://www.jacobinmag.com/2017/09/indiamodi-bjp-cow-vigilantism-judiciary-corruption; downloaded 25 January 2018.

Vanaik, A. (2018). Hindu authoritarianism and agrarian distress. OpenDemocracy. Net, February 2018. https://www. opendemocracy.net/openindia/achin-vanaik/hindu-authoritarianism-and-agrarian-distress; downloaded 5 February 2018.

Veltmeyer, H., \& Petras, J. F. (2014). The new extractivism: A post-neoliberal development model or imperialism of the twenty-first century? London: Zed Books.

Vergara-Camus, L., \& Kay, C. (2017). Agribusiness, peasants, left-wing governments, and the state in Latin America: An overview and theoretical reflections. Journal of Agrarian Change, 17(2), 239-257. https://doi.org/10.1111/joac.12215

VTsIOM (2018). Vybory Prezidenta Rossii 2018. Otkrytyye Dannyye Issledovaniy Obshchestvennogo Mneniya VTsIOM. Reyting Kandidatov [Election of the President of Russia 2018. Open Public Opinion Research Data VTsIOM. Rating of Candidates]. https://2018.wciom.ru/index.php?id=1234; downloaded 5 November 2018. 
Wainwright, H. (2018). A new politics from the left. London: Polity Press.

Weis, T. (2007). The global food economy: The battle for the future of farming. London: Zed Books.

White, B. (2018). Marx and Chayanov at the margins: Understanding agrarian change in Java. Journal of Peasant Studies, 45(5-6), 1108-1126. https://doi.org/10.1080/03066150.2017.1419191

White, M. M. (2017). 'A pig and a garden': Fannie Lou Hamer and the freedom farms cooperative. Food and Foodways, 25(1), 20-39. https://doi.org/10.1080/07409710.2017.1270647

Win, K. Z. (2018). How populism directed against minorities is used to prop up Myanmar's 'Democratic' revival. https:// www.opendemocracy.net/khin-zaw-win/how-populism-directed-against-minorities-is-used-to-prop-up-myanmar-sdemocratic-reviva; downloaded 18 October 2018.

Wittman, H., Desmarais, A., \& Weibe, N. (Eds.) (2010). Food sovereignty: Reconnecting food, nature and community. Halifax: Fernwood.

Wolf, E. R. (1969). Peasant wars of the twentieth century. New York: Harper \& Row.

Wolford, W. (2005). Agrarian moral economies and neoliberalism in Brazil: Competing worldviews and the state in the struggle for land. Environment and Planning A, 37(2), 241-261. https://doi.org/10.1068/a3745

Wolford, W. (2010). This land is ours now: Social mobilization and the meanings of land in Brazil. Durham, NC: Duke University Press.

Wolford, W., Borras, S. M., Hall, R., Scoones, I., \& White, B. (2013). Governing global land deals: The role of the state in the rush for land. Development and Change, 44(2), 189-210. https://doi.org/10.1111/dech.12017

Wright, E. O. (2016). Socialism and real utopias. In R. Hahnel, \& E. O. Wright (Eds.), Alternatives to capitalism: Proposals for a democratic economy (pp. 25-40). New York: Verso.

Ye, J., Wang, C., Wu, H., He, C., \& Liu, J. (2013). Internal migration and left-behind populations in China. Journal of Peasant Studies, 40(6), 1119-1146. https://doi.org/10.1080/03066150.2013.861421

Zasulich, V. (1983 [original 1881])). A letter to Marx. In T. Shanin (Ed.), Late Marx and the Russian road (pp. 98-99). London: Routledge and Kegan Paul.

How to cite this article: Borras Jr SM. Agrarian social movements: The absurdly difficult but not impossible agenda of defeating right-wing populism and exploring a socialist future. J Agrar Change. 2019;1-34. https:// doi.org/10.1111/joac.12311 